\title{
Bilim Tarihi Temelli Hikâyelerle Fen Öğretimi: \\ Tesla ve Volta Örneği*
}

\section{Bahar CANDAŞ, ${ }^{* *}$ Zeynep KIRYAK*** ve Suat ÜNAL****}

Öz: Bilimsel buluşların tarihsel gelişimini göstermenin en etkili yollarından biri bilim tarihi temelli hikâyelerle öğretimin gerçekleştirilmesidir. Bilim tarihi temelli hikâyelerle bilimsel kavramlar açıklanırken, öğrencilerin bu kavramları neden öğrenmeleri gerektiği de vurgulanmaktadır. Bunların yanı sıra, hikâyeler öğrencilerin motivasyonlarının artmasına, hayal güçlerinin geliştirilmesine ve karşılaştıkları durumlar farklı açılardan bakabilmelerine fırsat vererek anlamlı öğrenmeyi destekleyen öğretim araçlarıdır. Bu çalışmanın amacı elektrik konusunda bilim tarihi temelli hikâyelerin geliştirildiği ve kullanıldığı öğretim sürecinin tasarlanması ve öğretmen adaylarının bilim tarihi temelli hikâyelerle öğretim süreci hakkındaki düşüncelerinin belirlenmesidir. Çalışma bir özel durum çalışması olup fen bilgisi öğretmenliği ikinci sınıfına devam eden 11 öğretmen adayıyla yürütülmüştür. Tesla bobini ve Volta pilinin yapılışını temel alan bilim tarihi temelli hikâyelerle yürütülen öğretim müdahalesi LES modeli doğrultusunda yönlendirilmiştir. Çalışmada veri toplama aracı olarak öğretmen adaylarının öğretim müdahalesi hakkındaki görüşlerinin alındığı görüşme formları kullanılmıştır. Çalışma sonucunda, öğretmen adaylarının hikâyelerle öğretim ve fen bilimlerinde LES modelinin kullanılmasına yönelik olumlu görüşlere sahip oldukları tespit edilmiştir. Öğrenci merkezli öğretim uygulamalarının öneminin yoğun biçimde ifade edildiği göz önünde bulundurulduğunda bilim tarihi temelli hikâyelerle yürütülecek öğretim uygulamalarının öğrencilerin fen kavramlarını anlamalarına destekleyecek öğrenme ortamları sunacağı düşünülmektedir. Ayrıca, diğer fen konularının öğretiminde de bilim tarihi temelli hikâyelerin kullanılmasının ve buna yönelik öğretim uygulamalarının tasarlanmasının alana katkı sağlayacağı düşünülmektedir.

Anahtar Kelimeler: Bilim tarihi temelli hikâyeler, fen öğretimi, LES modeli.

\footnotetext{
* Bu çalışma XI. International Congress of Educational Research adlı kongrede sözlü bildiri olarak sunulmuştur.

${ }^{* *}$ Arş. Gör. Trabzon Üniversitesi, Lisansüstü Eğitim Enstitüsü, Matematik ve Fen Bilimleri Eğitimi ABD, Email: bhrcnds@gmail.com, Orcid No: 0000-0003-4516-9670.

${ }^{* * *}$ Arş. Gör. Trabzon Üniversitesi, Lisansüstü Eğitim Enstitüsü, Matematik ve Fen Bilimleri Eğitimi ABD, Email: zeynepkiryak@gmail.com, Orcid No: 0000-0002-8644-4336.

**** Prof. Dr. Trabzon Üniversitesi, Fatih Eğitim Fakültesi, Matematik ve Fen Bilimleri Eğitimi Bölümü, Email: : unal_suat@hotmail.com, Orcid No: 0000-0002-0495-8385
}

\begin{tabular}{lll}
\hline Gönderim:13.07.2020 Kabul:30.11.2020 & Yayın:25.01.2021
\end{tabular}




\section{Teaching Science with Stories Based on the History of Science:}

\section{Example of Tesla and Volta}

Abstract: One of the most effective ways of integrating the nature of science in science classes is using the historical developments of scientific discoveries. While studying on science concepts with story based on its history, learners realize why they should learn these concepts and understand the social relevance of science. Storytelling is accepted as a teaching strategy to encourage meaningful learning by allowing learners to increase their motivation, improve their imagination, and allow them to look at situations from different viewpoints. The aim of this study is to carry out two teaching implementations on electricity through stories based on the history of science with the prospective science teachers, and to determine their opinions on the stories based on history of science and the teaching processes. This study has been designed according to a holistic single case descriptive study approach and carried out with 11 volunteering second grade prospective science teachers. The intervention including the stories of the construction of the Tesla coil and the Voltaic pile is planned and conducted in line with the LES model. An interview protocol for determining prospective teachers' opinions on the stories and implementation process was used as data collection tool. As a result of the study, it was seen that story-based teaching process and LES model have positive effect on the prospective teachers' conceptual understandings. Besides, it was determined prospective teachers' have positive attitude and opinions on teaching intervention. It is thought that teaching including stories based on the history of science will support understanding science concepts in any subject.

Keywords: Storytelling based on history of science, science teaching, LES model.

\section{Giriş}

Toplumsal ve teknolojik değişimler sosyal yaşamı etkilerken; bu değişimlerin getirdiği yenilikler öğretim programlarının içeriğinin ve amaçlarının sorgulanmasını ve bu gelişmeler doğrultusunda çeşitli revizyonların yapılmasını gerekli kılmıştır. Tüm dünyada öğretim süreçlerinin hedeflerini şekillendirmede 21. yüzyıl becerileri kapsamında çeşitli yeniliklerin yapıldığı görülmektedir. $\mathrm{Bu}$ yeniliklerle birlikte öğrencilerden bilimsel konulara yönelik eleştirel düşünebilen, bilimsel olgu ve olayların değerini anlayabilen, etkili bilimsel iletişim ve problem çözme becerilerine sahip bireyler olmaları beklenmektedir (National Research Council [NRC], 2012; Organisation for Economic Co-operation and Development [OECD], 2013). Ülkelerin öğretim programlarında, bu becerileri öğrencilerine kazandıracak şekilde 
düzenlemeler yapması ülkemizde de öğretim programlarının yenilenmesi ile sonuçlanmıştır. $\mathrm{Bu}$ doğrultuda, öğretim programları incelendiğinde, öğrencilere bu becerilerin kazandırılmasına yönelik uygulamaların fen bilimleri derslerinde geniş yer bulduğu görülmektedir.

Mevcut 2018 fen bilimleri dersi öğretim programı da dahil olmak üzere, 2005 yılından itibaren fen öğretim programlarında özellikle bilimsel okuryazar bireylerin yetiştirilmesinin önemi üzerinde durulmaktadır. Bilimsel okuryazar bireylerden sadece fen kavramlarını öğrenmeleri değil, bu kavramların doğasını anlamaları da beklenmektedir. Bilimsel okuryazarlığın en önemli bileșenlerinden biri de bilimin doğasıdır. Bilimin doğasının göz ardı edildiği bir öğretim uygulamasıyla öğrenciler sadece teorik olarak ortaya koyulan bilgiyi öğrenebilmekte, bu bilginin ortaya çıkma sebepleri, üzerine çalışan bilim insanları, bilginin doğası ve sınırları hakkında herhangi bir sorgulama ya da öğretimle karşılaşmamaktadır (Eichinger, Abell ve Dagher, 1997; Kaya, 2007). Bu noktada, öğrencilerin bilimin doğasına yönelik bilgi sahibi olmalarında öğretmen rolü büyük önem arz etmektedir. Ancak, ulusal ve uluslararası literatürde öğretmenler ve öğretmen adaylarının bilimin doğası ve unsurları hakkında yetersiz bilgiye sahip oldukları ifade edilmektedir (Lederman, 1992; Abd-El-Khalick ve BouJaoude, 1997; Murcia ve Schibeci, 1999; Ochanji, 2003; Küçük, 2006; McDonald, 2010; Faikhamta, 2013; Mihlandiz ve Doğan, 2017; Polat, 2018).

Bilimin doğasının anlaşılmasında bilim tarihi vurgusu ve bilim tarihi temelli öğretim uygulamalarının etkili sonuçlar verdiği ifade edilmektedir (Justi ve Gilbert, 2000; Mısır ve Laçin-Şimşek, 2018). Bilim tarihi öğretimi ile öğrencilerin bilimin doğasını anlamaları, bilime karşı olumlu tutum geliştirmeleri ve bilimsel okuryazarlıklarının geliştirilmesi sağlanabilmektedir (Koştur, 2017; Lederman, 1998; Sönmez, 2008; Turgut, 2007). Bilimin tarihsel perspektifle sunulması öğrencilerin sadece kavramları ve kavramsal yapıları daha geniş bir bağlam içinde öğrenmelerini sağlamakla kalmamakta, aynı zamanda tarihsel süreçlere yönelik derinlemesine anlayışların geliştirilmesinde de önemli bir rol de oynamaktadır (Matthews, 2009). Bu sayede, öğrenciler bilimin teorik bilgi kalıplarının ötesinde tarihsel olarak gelişim süreçlerini ve bu süreçlerde ortaya çıkan fikir çatışmaları, zorluklar ve çözüme ulaşma yolları ile ilgili bakış açılarını geliştirme fırsatı bulabilmektedirler. Bu amaç doğrultusunda, bilime ve bilimsel çalışmalara yönelik tarihsel kısa olaylar öğretim sürecine kolaylıkla entegre edilebilmekte (Topdemir ve Unat, 2014) ve öğrencilere bilimin doğasına yönelik anlayışlar kazandırmanın yollarından biri olarak görülmektedir (Abd-El Khalick, 1999; Clough, 2006; Kaya, 2007; Rosell ve Vilumara, 2010). Bilim tarihi ve bilimin doğası öğretimi 
sayesinde, öğrencilerden bilimsel bilgilerin nasıl ortaya çıktığının, bu bilgilerin tarihsel süreç içerisinde zamanla nasıl geliştiğinin ve bu bilgilerin teknolojik gelişmelerin gerçekleşmesindeki rolünün farkında olan bireyler olmaları beklenmektedir (Yıldırım, 2016). Bu bağlamda, fen eğitimi aracılığıyla öğrencilere alana yönelik teorik bilgilerle birlikte bu bilgilerin açığa çıkmasını sağlayan bilim insanları, onların yürüttükleri çalışmalar, bu bilgilerin günümüze kadar gelmesinde hangi süreçlerden geçtiği ile ilgili bilgi verilmesi hedeflenmektedir. Böyle bir eğitimin verilmesi için ilk yapılması gereken şüphesiz öğretmenlerin ve öğretmen adaylarının bu tür öğretim uygulamalarına yönelik bilgilendirilmesi ve tecrübe edinmelerinin sağlanmasıdır. Bilimsel bilginin doğası ve gelişimine yönelik bahsedilen durumların farkına varmış bireyler yetiştirmede en etkili yollardan biri de bilim tarihi temelli hikâyelerle öğretimin gerçekleştirilmesidir. Bilim tarihi temelli hikâyeler ile bilimsel kavramlar açıklanırken, öğrencilerin bu kavramları neden öğrenmeleri gerektiği de vurgulanmaktadır (Klassen, 2009). Fen eğitiminin diğer bir amacı da öğrencilerin bilime ilgi ve merak duymalarını teşvik etmektir (Millar ve Osborne, 1998; Milli Eğitim Bakanlığı [MEB], 2018). Bu doğrultuda, ilgi çekici biçimde yazılan hikâyelerin öğrencilerde bilime yönelik merak, heyecan ve ilgiyi artıracağ ifade edilmektedir (Rowcliffe, 2004). Howe ve Johnson (1992), fen laboratuvarlarında hikâyelerden çeşitli şekillerde yararlanılabileceğini ifade etmektedir. Tarihi bağlamda hazırlanacak hikâyeler, öğrencilerin, insanların bugün bildiklerini bilmeden önce neler düşündüklerini anlamak, o gün için ortaya konulan bilginin bugüne gelene kadar ne gibi süreçlerden geçtiği üzerine düşünmek, kendisini o bilgiyi ortaya koyan kişinin yerine koymak ve onun karşılaştığı problemler ve çözümleri üzerinde düşünerek fikirler üretmek gibi açılardan oldukça faydalıdır. Bilim tarihi temelli hikâyeler öğrencilerin dünya hakkındaki anlayışının geliştirilmesine katkı sağlarken, bilim insanlarını tanımalarını ve bilimsel süreçler hakkında fikir sahibi olmalarını da sağlamaktadır (Wieder, 2006). Hikâyelerle gerçekleştirilen öğretim uygulamaları, öğrencilerin motivasyonlarının artmasına, hayal güçlerinin geliştirilmesine, problemleri çözmesine ve karşılaştıkları durumları sorgulamasına ve farklı açılardan yorumlayabilmesine firsat vererek anlamlı öğrenmeyi destekleyen öğretim araçlarından biri olarak kabul edilmektedir (Bertiz, 2005; Klassen, 2009; Şeker ve Welsh, 2006; Şimşek, 2006). Fen eğitiminde kullanılan hikâyeler öğrenilenlerin hatırlanması, fikirlerin geliştirilmesi, öğrencilerin tutum, his ve duygularını kullanmalarının sağlanması için güçlü bir etkiye sahiptir (Banister ve Ryan, 2001). Ayrıca, öğrencilerin sunulan konuyla ilgili zihinsel modellerinin açığa çıkarılması, hayal güçlerinin geliştirilmesi ve fikirlerini paylaşması açısından etkili bir yol olabilir (Demircioğlu, 2008). Bunun yanı sıra, hikâyelerin öğrencilerin seviyesine uygun 
bir öğretim yapılabilmesi ve etkili iletişim kurulabilmesi için önemli bir araç olduğu ifade edilmektedir (Ersoy ve Papatğa, 2015).

Ulusal ve uluslararası literatürde, fen eğitiminde açıklayıcı ve bilim tarihi temelli hikâyelerden yararlanan sınırlı sayıda çalışmanın bulunduğu görülmektedir. Bu çalışmaların bir kısmı bilim tarihi temelli hikâyelerin fen öğretiminde kullanılmasına yönelik teorik çalışmalar iken (Horton, 2013; Isabelle, 2007; Klassen, 2014; Klassen ve Froese-Klassen, 2014; Milne, 1998; Stinner ve Williams, 1993; Şeker, 2012), diğer bir kısmının çeşitli eğitim kademelerindeki öğrencilerle bilim tarihi temelli öğretim müdahalelerinin gerçekleştirildiği uygulamalı çalışmalar olduğu belirlenmiştir (Banister ve Ryan, 2001; Güney ve Seker, 2012; Kahraman, 2012; Kahraman ve Karataş, 2015; Kaya, 2007; Kokkotas, Rizaki ve Malamitsa, 2010; Polat ve Taşar, 2013; Roach ve Wandersee, 1995). İlgili literatüre bakıldığında, bilimin doğası, bilim insanlarının çalışmaları, bilimsel gelişmeler, bilimsel gerçeklerin ardında yatan olaylar ve toplumların bu gelişmelerden nasıl etkilendiğinin belirlenmesinde etkili bir yöntem olarak kabul edilen bilim tarihi temelli hikâyeler aracılığıyla fen öğretim uygulamalarına yönelik çalışmaların ülkemizde oldukça az sayıda araştırmacı tarafından yürütüldüğü görülmektedir (Güney ve Seker, 2012; Kahraman ve Karataş, 2015; Kaya, 2007; Mısır ve Laçin-Şimşek, 2018; Polat ve Taşar, 2013; Şeker, 2012). Eğitim fakültelerinin lisans programlarında yer alan Bilimin Doğası ve Bilim Tarihi gibi dersler, öğretmen adaylarının bu kavramlara yönelik teorik bilgi kazanmalarına fırsat verecek teorik içeriğe sahip olmasına rağmen, meslek yaşantılarında gerçekleştirecekleri öğretim uygulamalarında daha anlamlı öğrenmeleri sağlayabilmek adına fen kazanımlarını bilimin doğası ve bilim tarihiyle nasıl bütünleştirebileceklerine yönelik uygulamalara yeterli zaman ayrılmadığı düşünülmektedir. Bunun yanı sıra, yapılan çalışmalarda öğretmenlerin bilim tarihini önemli görmelerine rağmen, yürüttükleri derslerde bilim tarihine yönelik uygulamalara yer vermedikleri belirlenmiştir (Brush, 1974; Lin ve Chen, 2002; Misır ve Laçin-Şimşek, 2018; Wang, 1998; Wang ve Cox-Petersen, 2002; Wang ve Marsh, 2002). Bilimin Doğası ve Bilim Tarihi derslerinin keşifler tarihi şeklinde yürütülmesinin öğrencilerin öğrendiklerini fen öğretimi ile ilişkilendirmesini zorlaştırdığına yönelik literatürde öğreticilere yönelik çeşitli öneriler yer almaktadır (Brush, 1989; Laçin-Şimşek, 2009; Mısır ve Laçin-Şimşek, 2018; Yıldırım, 2016). Bu bağlamda, bilimin doğası ve bilim tarihi öğretiminde bilimsel kavram, teori ve anlayışların fen bilimleri derslerinin içeriği ile bütünleştirilmesine imkân verecek uygulamaların geliştirilmesi gerekmektedir.

Bilim tarihi temelli fen öğretiminin kavramsal (bilimsel fikirlerin anlamı ve bu fikirlerin bilim tarihindeki rolleri), yöntemsel (bilimsel düşünme ve deneysel süreçler) ve bağlamsal (bilim 
insanının karakteri, çalışma koşulları ve ekonomik, politik ve sosyal ortam) boyutlar üzerine yapılandırılması önemlidir (Wang, 1998). Bu bileşenlerin bütünleştirilmediği ya da göz ardı edildiği öğretim uygulamaları sonucunda öğrencilerin edinilen bilgilerin gelişim süreçlerinin farkında olmadıkları, ileriye yönelik gelişimsel süreçlerin tasarlanması ve yeni fikirlerin üretilmesi konusunda da eksik kalacakları düşünülmektedir. Buna karşın, literatürde yer alan çalışmalar hem öğretim programları ve ders kitaplarında yer alan bilgiler hem de gerçekleştirilen öğretim uygulamalarının çoğunlukla bilimin kavramsal boyutuna odaklandıklarını, yöntemsel ve bağlamsal boyutlarının ise göz ardı edildiğini göstermektedir (Laçin-Şimşek, 2009; Narguizian, 2002; Laçin-Şimşek 2011; Wang, 1998). Ayrıca, bilim tarihi temelli hikâyelerle öğretim üzerine yapılan sınırlı sayıdaki çalışmalar (Brito, Rodriguez ve Niaz, 2005; Clough, 2010; Demircioğlu, Ayas, Demircioğlu ve Özmen, 2015; Demircioğlu, Demircioğlu ve Çalık, 2009; Wieder, 2006) incelendiğinde, çalışmalarında kullandıkları bilim tarihi temelli hikâyeleri sayfa sayısı veya başka nedenlerle okuyucuya sunmadıkları, bu nedenle öğretmenlerin faydalanabilecekleri bilim tarihi temelli hikaye örneğinin literatürde pek de yer almadığı görülmektedir. Bu bağlamda, bu çalışmanın hem öğretmenler hem de öğretmen yetiştiriciler için bilim tarihi temelli hikâyelerin derste nasıl kullanılacağına yönelik örnek bir öğretim uygulamasına yer vermesi açılarından da literatüre önemli katkılar sağlayacağına inanılmaktadır. Bunun yanı sıra, gerçekleştirilecek uygulamanın bilimin kavramsal, yöntemsel ve bağlamsal yönlerini kapsayıcı öğretim uygulamalarının tasarlanması ve yürütülmesi ile ilgili araştırmacılara, öğretmenlere ve öğretmen adaylarına fikir vereceği düşünülmektedir. Ayrıca, bilim tarihi temelli hikayelerin genellikle kimya konularını içeren çalışmalarda sıklıkla kullanılırken (Brito ve diğ., 2005; Demircioğlu ve diğ., 2015; Demircioğlu ve diğ., 2009; Kahraman ve Karataş, 2015; Wieder, 2006), fizik (Güney ve Şeker, 2012; Kokkotas ve diğg, 2010) ve biyoloji (Wieder, 2006) konularında yürütülen çalışmalar oldukça sınırlıdır. Bilim tarihi temelli hikayelerin öğrencilerin kavramı ve kavramın gelişim sürecini anlama ve bilim insanın gözünden süreci yaşamalarına firsat verdiği düşünüldüğünde fizik ve biyoloji alanlarında da bu tür çalışmaların yürütülmesinin önemli olduğu düşünülmektedir. Özellikle, elektrik ve elektrik konusu ile ilgili birçok temel fizik kavramının günlük dilde farklı anlamda kullanılması (Duit ve Rhöneck, 1997), öğrencilerin bilimsel gerçeklikten uzak düşünceleri benimsemelerine sebep olmaktadır (Çepni ve Keleş, 2006; Demirci ve Çirkinoğlu, 2004; Dilber ve Düzgün, 2008). Bu durumda öğrencilerin zihinlerinde oluşan karmaşıklığın giderilmesi için alternatif yöntemlerden biri olan hikayelerin faydalı olacağına inanılmaktadır. Yukarıda ifade 
edilen sebeplerden dolayı bu çalışmada geliştirilen bilim tarihi temelli hikayeler elektrik konusu bağlamında tasarlanmıştır.

$\mathrm{Bu}$ çalışmanın amacı, fen bilgisi öğretmen adaylarının bilgi sahibi oldukları elektrik konusuna farklı perspektiften bakmalarını sağlamaya yönelik bilim tarihi temelli hikâyelerin geliştirilmesi, hikâyeleri içeren öğretim sürecinin tasarlanması ve öğretmen adaylarının bilim tarihi temelli hikayelerle öğretim süreci hakkındaki düşüncelerinin belirlenmesidir.

\section{Yöntem}

\section{Araştırma Deseni}

Bilim tarihi temelli hikâyelere dayalı öğretim sürecinin tasarlanması ve öğretim sürecine yönelik öğretmen adaylarının görüşlerinin belirlenmesini amaçlayan bu çalışma betimleme amaçlı durum çalışması yaklaşımına göre dizayn edilmiştir. Öğretim sürecinin tasarlanması ve sürece yönelik aday görüşlerinin belirlemesi durumları, birbirleri içinde tek bir durum olarak incelendiği için çalışma bütüncül tek duruma göre desenlenmiştir (Yin, 2003).

\section{Çalışma Grubu}

Çalışma fen bilgisi öğretmenliği ikinci sınıfa devam eden, elektrik konularının işlendiği Genel Fizik-II ve Genel Fizik Laboratuvarı-II derslerini tamamlamış öğretmen adaylarından gönüllü olarak belirlenen 19 öğretmen adayı ile yürütülmüştür. Çalışmada, öğretmen adaylarına teorik bilgi kazandırmak hedeflenmediği için ve adayların uygulama sürecinde deney tasarlamaları ve temel fizik konularına yönelik fikir yürütmeleri beklendiğinden belirtilen dersleri tamamlamış olmaları beklenmektedir. Bu nedenle öğretmen adaylarının teorik ve uygulamalı olarak bilgi sahibi oldukları elektrik konusu kapsamında iki bilim tarihi temelli hikaye kullanılarak farklı bir çerçeveden sahip oldukları bilgiler üzerinden bakış açılarının geliştirilmesi hedeflenmektedir. Öğretmen adayların bir kısmı iki hafta boyunca süren uygulamaların tamamına devam edememiştir, bu sebeple sürecin tamamına katılan 11 öğretmen adayının verileri çalışmaya dahil edilmiştir.

\section{Veri Toplama Araçları ve Analizi}

Öğretmen adaylarının gerçekleştirilen öğretim sürecine yönelik görüşlerini belirlemek ve derinlemesine incelemek amacıyla başlangıçta dört açık uçlu sorudan oluşan bir görüşme formu veri toplama aracı olarak çalışmanın yazarları tarafından geliştirilmiştir. Bu form Fen Eğitimi alanında uzman bir öğretim üyesinin görüşleri doğrultusunda düzenlenerek çalışmada kullanılan ve 6 açık uçlu sorudan oluşan son hali verilmiştir. Yapılan düzenlemelerde şunlardır: Örneğin 1. soru daha detaylı bilgi elde etmek amacıyla genişletilmiştir. 1. soruda gerçekleştirilen öğretim sürecinde öğretmen adaylarının beğendikleri ve beğenmedikleri 
yönleri ayrı olarak belirtmesi adına soruya ikinci kısım ilavesi yapılmıştır. Ayrıca formun ilk halinde “Gerçekleştirilen öğretim sürecinin size nasıl bir katkısı olduğunu düşünüyorsunuz?” şeklinde yer alan üçüncü sorusunun genel olarak öğretim sürecinin bütününe yönelik olması yerine, uzman öğretim üyesinin görüşü doğrultusunda bu soru süreçte kullanılan hikaye, deney ve tartışmalarla ilgili görüşleri spesifik olarak alabilmek adına üç farklı soru olarak daha spesifik şekilde öğretmen adaylarına yöneltilmiştir. Buna göre, son hali altı açık uçlu soru içeren görüşme formu, uygulama bitiminde öğretmen adaylarına uygulanmıştır. Görüşme formunun son halinde yer alan sorular şöyledir; 1) Genel olarak gerçekleştirilen öğretim süreci hakkında ne söylersiniz? Uygulamanın beğendiğiniz veya beğenmediğiniz yönleri var mıydı, varsa nelerdir?, 2) Öğretmen olduğunuzda benzer bir öğretim sürecini derslerinizde kullanmayı tercih eder misiniz?, 3) Uygulamada kullanılan hikayelerin size veya ögrenmeögretme sürecine nasıl bir katkısı olduğunu düşünüyorsunuz?, 4) Uygulamada kullanılan deneylerin size veya öğrenme-öğretme sürecine nasıl bir katkısı olduğunu düşünüyorsunuz?, 5) Uygulamada gerçekleştirilen tartışmaların size veya öğrenme-öğretme sürecine nasıl bir katkısı olduğunu düşünüyorsunuz?, 6) Sizce öğretim sürecinde kullanılan yöntemlerden herhangi biri olmasaydı süreç nasıl değişirdi? Her bir bileşen için ayrı ayrı fikirlerinizi belirtiniz? şeklindedir. Görüşme formundan elde edilen veriler içerik analizine tabi tutulmuştur. Sorulara verilen cevaplar iki araştırmacı tarafından bağımsız olarak kodlanmış ve temalar oluşturulmuştur. Analize ilişkin güvenirlik Görüş Birliği/(Görüş Birliği+Görüş Ayrıllı̆ı) formülü kullanılarak 0,87 olarak hesaplanmıştır. $\mathrm{Bu}$ değer, literatürde ifade edilen 0,80 değerinin üzerinde olduğu için sonuçların güvenilir olduğuna karar verilmiştir (Miles ve Huberman, 1994). Bağımsız analizlerden sonra iki araştırmacı bir araya gelmiş ve analizlerini karşılaştırarak, ortak kod ve kategoriler üzerinde fikir birliğine varmışlardır. Fikir ayrılığı görülen analizler için alan uzmanının görüşleri alınmış ve ortak kararlara varılmıştır. Her bir soru için oluşturulan kodlar ve temalar tablolar halinde bulgular bölümünde sunulmuştur.

\section{Uygulama Süreci}

Bilimin doğası öğretiminde Akerson, Abd-El-Khalick ve Lederman (2000) doğrudan-yansıtıc1, dolaylı ve tarihsel yaklaşım olmak üzere üç yaklaşım bulunduğunu ifade etmektedir. Tarihsel olaylar üzerine yapılandırılan bu çalışma, önerilen yaklaşımlardan tarihsel yaklaşım göz önünde bulundurularak tasarlanmıştır. Tarihsel yaklaşım bilimi sosyal bağlamda ele almakta ve bilim ve teknolojideki gelişmeleri sosyal ve tarihsel bağlamlarda inceleyerek kavramların bu yolla geliştirilmesini önermektedir (McComas ve Olson, 2000). 
Uygulamalara başlamadan önce bilim tarihi temelli hikâyelerin yazımı gerçekleştirilmiştir. Hikâye yazımı ve uygulama süreci için Klassen ve Froese-Klassen (2014) tarafindan hikâyelerin biçimsel olarak sahip olması gereken beş ve içerik olarak sahip olması gereken altı temel özellik göz önünde bulundurulmuştur. Biçimsel olarak belirlenen özellikler: (1) Karakterler: Bilim tarihinde önemli bir yere sahip olan ana karakter ya da karakterler belirlenir. (2) Olaylar: Tarihsel süreçte gerçekleşen olaylar dizisi literatürle desteklenerek verilir. (3) Durumlar: Karakterin karşılaştığı olaylar ve bu olaylara verdiği tepkiler işlenir. (4) Sonuç: Olaylar ve durumlardan elde edilen sonuçlar birbirini takip eden bir süreç izlenerek sunulur. (5) Geçmiş Zaman: Olaylar bir anlatıcı tarafından geçmiş zaman ifadeleriyle yazılırken, anlatıcı içinde bulunulan zamanda yaptığı konuşmaları şimdiki zaman ifadeleriyle belirginleştirebilir. İçerik olarak sahip olması gereken özellikler: (1) Ortam: Olayların geçeceği zaman ve mekân belirlenerek tanımlanır. (2) Problem durumu: Bilimsel olgular çerçevesinde bir problem durumu açığa çıkarılır. (3) Kriz dönemi: hikâye ana karakterin eylemde bulunmasını gerektirecek kritik bir noktaya gelir. Kriz dönemi ahlaki, zihinsel, fiziksel, durumsal ya da bunların birkaçını içerecek nitelikte olabilir. (4) Kritik karar verme: Ana karakterin ciddi bir seçim yapması beklenir. (5) Dönüm noktası: Hikâyenin dönüm noktasına ulaşıldığında, olaylar hızla iyi ya da kötü yöne doğru gelişmeye başlar. (6) Olayların çözülmesi ve sonuç: Problem durumu olumlu ya da olumsuz bir şekilde sonuçlandırılır.

$\mathrm{Bu}$ doğrultuda, belirtilen kriterlere uygun olarak çalışmada Volta pili ve Tesla bobininin yapımını temel alan iki hikâye geliştirilmiştir. Volta Pili hikâyesi, Volta'nın, Galvani'nin ortaya attığı hayvansal elektrik iddialarını çürütmesi üzerine kurgulanmıştır. Çeşitli bilimsel kaynaklardan (Finger, Piccolino ve Stahnisch, 2013a; 2013b; Tez, 1983) yararlanılarak oluşturulan hikâyeye, okuyucunun dikkatini çekmesini sağlamak amacıyla kurgusal olaylar eklenmiştir. Tesla bobini hikâyesinin yazımında Tesla'nın sonsuz elektrik üretmek adına yürüttüğ̈̈ çalışmalar ve bu süreçte karşılaştığı zorluklar üzerine kurgulama yapılmıştır. Hikâyenin gerçeğe yakınlığının sağlanması için Margaret Cheney tarafından yazılan Tesla: Man Out of Time kitabı ve çeşitli bilimsel kaynaklardan (Martin, 1894; O'neill, 2007) elde edilen bilgiler doğrultusunda kurgulama yapılmıştır. Tablo 1'de geliştirilen hikâyelerin içerik kriterlerine yönelik sahip olduğu özellikler gösterilmiştir.

Tablo 1. Hikayelerin İçerik Unsurları Bağlamında Özellikleri

\begin{tabular}{lll}
\hline $\begin{array}{l}\text { İçerik } \\
\text { unsurları }\end{array}$ & Volta pili & Tesla bobini \\
\hline \multirow{2}{*}{ Ortam } & Hikâye 1700'lü yıllarda Kraliyet & Hikâye 1800'lü yılların sonunda Amerika'da \\
bilimler akademisinde gerçekleştirilen & geçmektedir. Hikâyede Tesla'nın elektrik ile \\
bir toplantıda geçmektedir. Hikâyede & ilgili çalışmaları, tüm insanlığa hizmet edecek \\
\hline
\end{tabular}


ilk basit pilin üretilme sürecinde Volta icatlar üretme çabas1 ve bu süreçte karş1aştığ1 ve Galvani arasındaki bilimsel zorluklar anlatılmıştır. mücadele anlatılmıștır.

\begin{tabular}{|c|c|c|}
\hline & $\begin{array}{l}\text { Hikâyede Galvani ve Volta'nın } \\
\text { elektrik akımının kaynağının ne olduğu } \\
\text { ile ilgili anlaşmazlığa düşmesi konu } \\
\text { edinilmiştir. }\end{array}$ & $\begin{array}{l}\text { biri olan kablosuz elektrik enerjisi iletimini } \\
\text { sağlamak için yürüttüğü çalışmalar ve bu } \\
\text { süreçteki mücadelesi betimlenmiştir. }\end{array}$ \\
\hline riz & 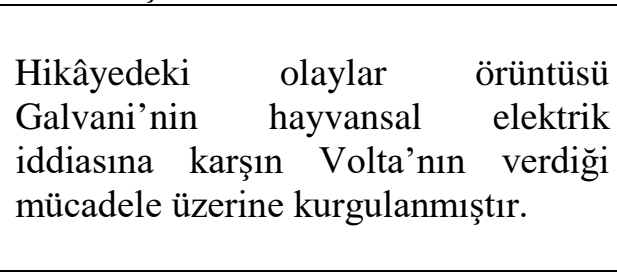 & $\begin{array}{l}\text { Hikâyede, diğer bilim insanlarının ve } \\
\text { yatırımcıların Tesla'ya destek vermemesi, } \\
\text { çalışmalarını yürüttüğğ çevrede yaşayan } \\
\text { insanların tedirgin olmalarıyla Tesla'nın } \\
\text { çalışmalarında yaşanan aksaklıklar konu } \\
\text { edinilmiştir. }\end{array}$ \\
\hline & 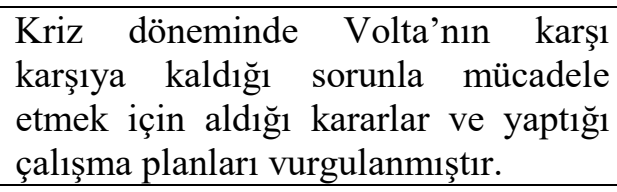 & $\begin{array}{l}\text { lternatif yollar bu } \\
\text { r. }\end{array}$ \\
\hline & $\begin{array}{l}\text { Kraliyet bilimler akademisinde } \\
\text { yaşanan tartışmada bilim insanlarının } \\
\text { büyük kısmının Galvani’nin görüşünü } \\
\text { desteklemesi üzerine Volta'nın kendi } \\
\text { iddiasını ispatlamak için yürüttüğü } \\
\text { çalışmalar ele alınmıştır. }\end{array}$ & $\begin{array}{l}\text { Newyork Elektrik Cemiyeti'nin başkanı ve } \\
\text { üyeleri olan Pupin, Edison ve Marconi } \\
\text { tarafından Tesla'nın çalışmalarının ticari } \\
\text { kaygılarla onaylanmamas ve halkın bu } \\
\text { doğrultuda kışkırtılması ele alınmıştır. }\end{array}$ \\
\hline & $\begin{array}{l}\text { Volta'nın hem kendi icadını kesin } \\
\text { kanıtlarla ortaya koyması hem de } \\
\text { Galvani'nin öne sürdüğü deneyi } \\
\text { defalarca yapması sonucu onun savını } \\
\text { çürütecek verilere ulaşması ile } \\
\text { sonuçlandırılmıştır. }\end{array}$ & $\begin{array}{l}\text { Hikâye, Tesla çalışmalarını güçlükle } \\
\text { tamamlasa da tüm yatırımcıların ekonomik } \\
\text { desteğini çekmesi ve borçlarını ödeyemediği } \\
\text { için çalışmalarını hayata geçirememesi, ancak } \\
\text { yıllar sonra Amerikan Elektrik Mühendisleri } \\
\text { Enstitüsü tarafindan ödüle layık görülüşü ile } \\
\text { sonuçlandırılmıştır. }\end{array}$ \\
\hline
\end{tabular}

Tablo 1'de içerik unsurları verilen hikâyede biçimsel unsurlara bakıldığında, karakterler ortam başlığı altında tanıtılırken, olaylar unsuru problem durumu başlı̆̆ı ile örtüşmektedir. Durumlar unsuru ise, kriz dönemi, kritik karar verme ve dönüm noktası başlıklarının üçünü kapsarken, sonuç unsuru olayların çözülmesi ve sonuç başlığı ile uyumludur. Biçimsel unsurların sonuncusu olan geçmiş zaman ise hikâyenin tamamında kullanılan dil yapısını oluşturmaktadır. Hikâyeler öğretmen adaylarına sunulurken hikâyenin içeriğine uygun resimlerle kitapçık haline getirilmiştir. Her iki kitapçık dörder sayfadan oluşmaktadır.

Bilim tarihi temelli hikâyelerin uygulanmasında öğretim yöntemi olarak sorgulayıcı öğrenmeyi destekleyen LES (Launch, Explore, Summarize) modeli seçilmiştir. Girme, Keşfetme ve Özetleme aşamalarından oluşan LES modeli fen kavramlarının öğrenilmesinde ve öğretilmesinde sorgulayıcı bir öğretimin gerçekleşmesini sağlar. Üç aşamalı modelin ilk aşaması olan girme (launch) aşamasında, öğrencilerin ön bilgilerini ve yeni öğrenilecek kavramla ilişkili diğer bilgilerini hatırlatmak ve ortaya çıkarmak amacıyla bazı araştırma soruları kullanır. Ayrıca bu aşamada öğrenciler ele alınacak konu/problem üzerinde 
düşünmeleri ve tartışmaları için teşvik edilir. İkinci aşama olan keşfetme (explore) aşamasında, öğrencilerin ele alınacak konuyla ilgili olarak ilk elden deneyim kazanmalarını sağlayacak uygulamalar yapılır ve verilmesi gereken kavram, teori ya da yasa onlara açıklanır. Bu aşamada hikâyelere yer verilebilir. Son aşama olan özetleme (Summarize) aşamasında ise, öğrencilerin öğrendikleri bilgileri yeni durumlara uygulamaları, öğrendikleri bilgilerle gerçek yaşamdaki durumlar arasında karşılaştırmalar ve tartışmalar yapmaları beklenmektedir (Isabelle, 2007).

Volta pili ve Tesla bobini için LES modeline göre gerçekleştirilen öğretim süreçlerine yönelik planlama Tablo 2'de verilmiştir.

Tablo 2. LES Modeline Göre Tasarlanan Öğretim Süreci

\begin{tabular}{|c|c|c|}
\hline LES & Volta Hikayesi & Tesla Hikayesi \\
\hline $\mathbf{L}$ & $\begin{array}{l}\text { - Hikâye okuma ile sürecin başlatılması } \\
\text { - Kritik noktalarda hikâyeye ara verilerek sınıf ta } \\
\text { - Ana karakterin karşılaştı̆̆ probleme çözüm bu }\end{array}$ & $\begin{array}{l}\text { artışmalarının yürütülmesi } \\
\text { lmasından önce okumanın sonlandırılmas1 }\end{array}$ \\
\hline $\mathbf{E}$ & $\begin{array}{l}\text { - Pilin nası yapıldı̆̆ ile ilgili kısım } \\
\text { okunmadan önce öğretmen adaylarının Volta } \\
\text { pilini test etmek için kendi deneylerini } \\
\text { tasarlamaları } \\
\text { - Hikâyede ilgili kısmın okunması } \\
\text { - Volta pili düzeneğinin kurulması ve } \\
\text { çalıştırılması } \\
\text { - Ögretmen adaylarının pilin çalışma } \\
\text { prensibine yönelik görüşlerinin alınması } \\
\text { - Deneysel sürecin ve hikâyenin tartışma ve } \\
\text { açıklamalara tamamlanması }\end{array}$ & $\begin{array}{l}\text { - Öğretmen adaylarının Tesla'nın } \\
\text { çalışmalarını yürüttüğü kablosuz elektrik } \\
\text { iletimini sağlamaya yönelik kendi } \\
\text { tasarımlarını yapmaları } \\
\text { - Hikâyede ilgili kısmın okunması } \\
\text { - Tesla bobini düzeneği üzerinden çalışma } \\
\text { prensibi ile ilgili tartı̧maların } \\
\text { yürütülmesi } \\
\text { - Deneysel sürecin ve hikâyenin tartışma } \\
\text { ve açılklamalara tamamlanması }\end{array}$ \\
\hline $\mathbf{S}$ & $\begin{array}{l}\text { - Volta pilinin avantajları ve dezavantajları } \\
\text { hakkında tartışmaların yürütülmesi } \\
\text { - Günümüzde kullanılan pil türleri, bu pillerin } \\
\text { kullanım alanları ile avantajları ve } \\
\text { dezavantajları hakkında ögretmen } \\
\text { adaylarının görüşlerinin alınması }\end{array}$ & 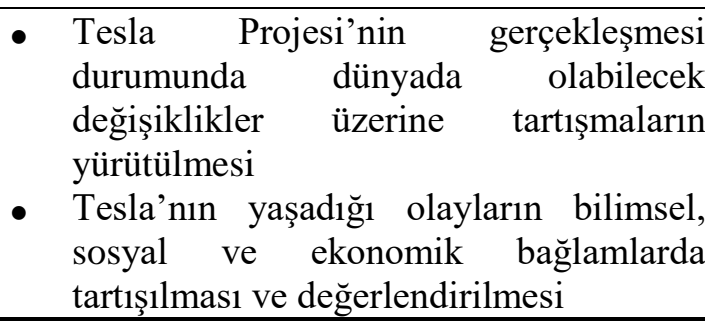 \\
\hline
\end{tabular}

Öğretim uygulaması altı saatlik süre içerisinde fizik laboratuvarında gerçekleştirilmiştir. Volta pili ve Tesla bobinine yönelik araştırmacılar tarafından yazılan iki bilim tarihi temelli hikâye aracılığıyla hem tartışma ortamının oluşturulması hem de deneylerin gerçekleştirilmesi hedeflenmiştir. Her uygulamadan önce ilgili hikâye basılı olarak her bir öğretmen adayına dağıtılmıştır. Okuma, sorgulama ve tartışmaların eş zamanlı gerçekleştirilebilmesi adına hikayeler bir kişi tarafından sesli okumuştur. Bu süreçte, hikâyeye araştırmacılar tarafından önceden belirlenen kritik noktalarda ara verilerek yönlendirici sorularla öğretmen adaylarının görüşleri alınmış ve birbirleriyle bu görüşler üzerinden tartışmalarına, fikirlerini savunmalarına ya da değiştirmelerine fırsat verecek iletişim ortamı sağlanmıştır. Tartışmaların yanı sıra, her 
hikâyenin ilgili aşamasında deneyler öğretmen adaylarıyla birlikte gerçekleştirilmiş ve hikâye sonuçlandırılmıştır. Sürecin sonunda öğretmen adayları görüşme formlarını cevaplandırmıştır.

\section{Bulgular}

Gerçekleştirilen öğretim uygulamaları sonrasında öğretmen adaylarının görüşme formlarından elde edilen veriler tablolar halinde sunulmuştur.

Genel olarak gerçekleştirilen ögretim süreci hakkında ne söylersiniz? Uygulamanın beğendiğiniz veya beğenmediğiniz yönleri var mıydl, varsa nelerdir? sorusuna verilen cevaplar Tablo 3'te sunulmuştur.

Tablo 3. Görüşme Formunun Birinci Sorusundan Elde Edilen Bulgular

\begin{tabular}{|c|c|c|c|c|}
\hline Kategori & Kod & $\begin{array}{l}\text { Öğretmen } \\
\text { adayı }\end{array}$ & f & Örnek cevap \\
\hline \multirow{4}{*}{ 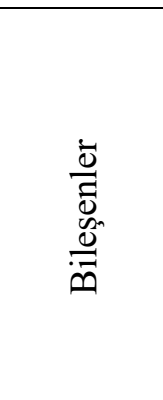 } & Deneyler & $\begin{array}{l}\text { Ö2, Ö3, Ö4, } \\
\text { Ö7, Ö10, } \\
\text { Ö11 }\end{array}$ & 6 & \multirow{9}{*}{$\begin{array}{l}\text { Ö2. Soru-cevap şeklindeki bireyselliğe dönük } \\
\text { tartışmalar olmasını ve olayları hikâye } \\
\text { şeklinde sunulmasını çok beğendim. Ama } \\
\text { teoriyi pratiğe dökmek için yapılan deneyler } \\
\text { benim en beğendiğim kısımlardı. }\end{array}$} \\
\hline & Hikâye & $\begin{array}{l}\text { Ö1, Ö2, Ö5, } \\
\text { Ö7, Ö10 }\end{array}$ & 5 & \\
\hline & Tartışmalar & $\begin{array}{l}\text { Ö2, Ö7, Ö8, } \\
\text { Ö10 }\end{array}$ & 4 & \\
\hline & Soru-cevap & Ö2, Ö10 & 2 & \\
\hline \multirow{5}{*}{ 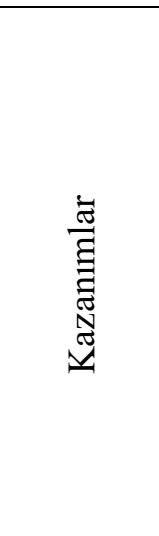 } & Deneyim kazanma & Ö5 & 1 & \\
\hline & Beyin firtınas1 & Ö6 & 1 & \\
\hline & $\begin{array}{l}\text { Düşünmeye sevk } \\
\text { etmesi }\end{array}$ & Ö8 & 1 & \\
\hline & $\begin{array}{l}\text { Empati yapmayı } \\
\text { sağlama }\end{array}$ & Ö9 & 1 & \\
\hline & $\begin{array}{l}\text { Beceri kazandırma, } \\
\text { hayal gücünü ortaya } \\
\text { çıarma, eksikliklerini } \\
\text { keşfedebilme, } \\
\text { fikirlerini savunmayı } \\
\text { öğretme... }\end{array}$ & Ö10 & 1 & \\
\hline
\end{tabular}

Tablo 3'te öğretmen adaylarının cevaplarının bileşenler ve kazanımlar olmak üzere iki kategori altında toplandığı, bu soruda herhangi bir olumsuz görüşün açığa çıkmadığı görülmektedir. Bileşenler kategorisi altında uygulamanın en beğendikleri yönleri olarak deney, hikâye, tartışma ve soru-cevap kodları öğretmen adayları tarafından ifade edilmiştir. Ayrıca, kazanımlar kategorisi altında sürecin düşünmeye sevk etmesi, fikirlerini savunma ve empati yapılmasına olanak vermesi gibi kodlar bu soruda açığa çıkmıştır. Öğretmen adaylarının verdikleri örnek cevaplarda da uygulamanın tüm aşamalarıyla beğenildiği, bu sayede düşünme ve deneyim kazanma firsatı bulduklarına yönelik düşüncelerinin oluştuğu görülmektedir. 
Öğretmen olduğunuzda benzer bir öğretim sürecini derslerinizde kullanmayı tercih eder misiniz? sorusuna verilen cevaplar Tablo 4'te sunulmuştur.

Tablo 4. Görüşme Formunun İkinci Sorusundan Elde Edilen Bulgular

\begin{tabular}{|c|c|c|c|c|}
\hline Kategori & Kod & $\begin{array}{l}\begin{array}{l}\text { Öğretmen } \\
\text { adayı }\end{array} \\
\end{array}$ & $\mathbf{f}$ & Örnek cevap \\
\hline \multirow{6}{*}{ 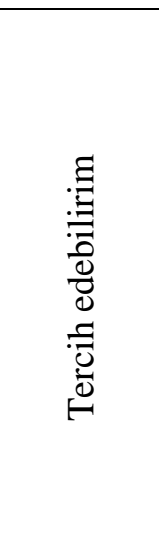 } & $\begin{array}{l}\text { Öğrencileri aktif } \\
\text { tutması }\end{array}$ & Ö1 & 1 & \multirow{6}{*}{$\begin{array}{l}\text { Ö1. Öğrencileri aktif tutmak iyi olacaktır. } \\
\text { Ö2. Eğer zaman yönünden tasarruflu olabilirsem } \\
\text { yapmak isterim. Ama sınıfın kalabalığı, zaman } \\
\text { k1sitll1ığ1 ve bulunduğum bölgeler de engel olarak } \\
\text { karşıma çıabilir. } \\
\text { Ö7. Dikkat çekici, merak uyandırıcı olduğu için } \\
\text { olabilir. Hem öğrencilerin belli konular hakkında } \\
\text { düşüncelerini dile getirmeyi sağlamaları için ortam } \\
\text { hazırlanmış olur. }\end{array}$} \\
\hline & $\begin{array}{l}\text { Sinıfın kalabalık } \\
\text { olmaması }\end{array}$ & Ö2 & 1 & \\
\hline & $\begin{array}{l}\text { Zamanın yeterli } \\
\text { olmas1 }\end{array}$ & Ö2 & 1 & \\
\hline & Dikkat çekici & Ö7 & 1 & \\
\hline & Merak uyandırıcı & Ö7 & 1 & \\
\hline & $\begin{array}{l}\text { Düş̋̈ncelerin } \\
\text { açığa çıkarılması }\end{array}$ & Ö7 & 1 & \\
\hline \multirow{14}{*}{ 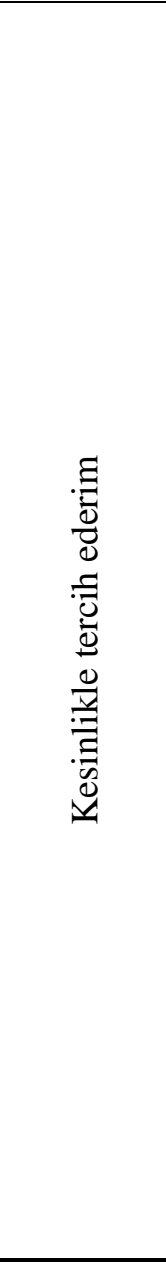 } & İlgi çekme & $\begin{array}{l}\text { Ö3, Ö8, } \\
\text { Ö11 }\end{array}$ & 3 & \multirow{14}{*}{$\begin{array}{l}\text { Ö4. Bu tarz bir uygulamanın daha kalıcı olacağını } \\
\text { düşünüyorum. Özellikle konunun hikâyeye } \\
\text { dönüştürülerek anlatılması. } \\
\text { Ö5. Bu tarz etkinliklerle anlatılan şeylerin daha } \\
\text { sağlam ve kalıcı öğrenme sağladığını düşünüyorum. } \\
\text { Öğrencileri bir anda fazlaca teorik bilgiye } \\
\text { boğmaktansa bilgiyi daha eğlenceli bir halde onlara } \\
\text { aktarmak ve düşünmelerini araştırmalarını } \\
\text { sağlamak oldukça başarılı bir öğretme yöntemidir. } \\
\text { Ö6. ... fikir paylaşarak bir şeyler öğrendik. Hem } \\
\text { konuyla ilgili hem de bize genel kültür kazandıracak } \\
\text { şeyler öğrendik. Bunları öğrenirken zorlanmadık ve } \\
\text { kalıcı bilgi oldu. }\end{array}$} \\
\hline & Kalıcılik & $\begin{array}{l}\text { Ö3, Ö4, Ö5, } \\
\text { Ö6, Ö8, } \\
\text { Ö11 }\end{array}$ & 6 & \\
\hline & Eğlenceli & Ö5, Ö8 & 2 & \\
\hline & $\begin{array}{l}\text { Düşünmeyi } \\
\text { sağlama }\end{array}$ & Ö8 & 1 & \\
\hline & $\begin{array}{l}\text { Araştırmayı } \\
\text { sağlama }\end{array}$ & Ö5 & 1 & \\
\hline & $\begin{array}{l}\text { Fikir paylaşımı } \\
\text { sağlama }\end{array}$ & Ö6 & 1 & \\
\hline & $\begin{array}{l}\text { Konuyla ilgili } \\
\text { bilgi edinme }\end{array}$ & Ö6, Ö11 & 2 & \\
\hline & $\begin{array}{l}\text { Genel kültür } \\
\text { kazandırma }\end{array}$ & Ö6 & 1 & \\
\hline & Kolay öğrenme & Ö6 & 1 & \\
\hline & $\begin{array}{l}\text { Düşüncelerini } \\
\text { dile getirmeyi } \\
\text { sağlama }\end{array}$ & Ö7 & 1 & \\
\hline & Konuyu kavratma & Ö10 & 1 & \\
\hline & $\begin{array}{l}\text { Konuyu } \\
\text { kavratma, }\end{array}$ & & & \\
\hline & $\begin{array}{l}\text { Beceri ve } \\
\text { yeteneklerin } \\
\text { gelişmesini } \\
\text { destekleme }\end{array}$ & Ö10 & 1 & \\
\hline & Fayda sağlama & Ö9 & 1 & \\
\hline
\end{tabular}

Tablo 4’e göre, üç öğretmen adayı bu tarz bir uygulamayı kendi sınıflarında kullanmayı tercih etme konusunda "tercih edebilirim" cevabını verirken, sekiz öğretmen adayı "kesinlikle tercih ederim" cevabını vermiştir. Ayrıca, hiçbir öğretmen adayının bu tarz bir uygulamayı 
mesleğimde kullanmayı tercih etmem şeklinde bir açıklama yapmadığı belirlenmiştir. "Tercih edebilirim" cevabını veren öğretmen adaylarının cevaplarına bakıldığında ögrrencileri aktif tutmak, merak uyandırmak ve ilgi çekmek için iyi bir yöntem olacağı, ancak zaman, sınıf mevcudu ve okulun diğer koşullarının uygun olmaması durumunda kullanmakta zorlanacaklarını ifade etmişlerdir.

Uygulamada kullanılan hikâyelerin size veya ögrrenme-öğretme sürecine nasıl bir katkısı olduğunu düşünüyorsunuz? sorusuna verilen cevaplar Tablo 5 'te sunulmuştur.

Tablo 5. Görüşme Formunun Üçüncü Sorusundan Elde Edilen Bulgular

\begin{tabular}{|c|c|c|c|c|}
\hline Kategori & Kod & $\begin{array}{l}\text { Öğretmen } \\
\text { adayı }\end{array}$ & f & Örnek cevap \\
\hline \multirow{4}{*}{ 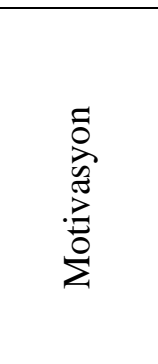 } & $\begin{array}{l}\text { İlgi-dikkat } \\
\text { çekme }\end{array}$ & $\begin{array}{l}\text { Ö1, Ö5, Ö7, } \\
\text { Ö8, Ö9 }\end{array}$ & 5 & \multirow{5}{*}{$\begin{array}{l}\text { Ö2. Kolay anlaşılması, sanki oradaymış gibi hissetme } \\
\text { ve konuyu daha rahat anlamamızı sağladı. } \\
\text { Ö3. Hikâyenin olması daha akılda kalıcı olmasını } \\
\text { sağladı. } \\
\text { Ö6. Hikâye sürükleyiciydi ve merak uyandırıcıydı.... } \\
\text { böylece sıkılmadan dinledik, anlatılanları kolayca } \\
\text { kavradık. }\end{array}$} \\
\hline & $\begin{array}{l}\text { Merak } \\
\text { uyandırma }\end{array}$ & $\begin{array}{l}\text { Ö6, Ö7, Ö8, } \\
\text { Ö9 }\end{array}$ & 4 & \\
\hline & $\begin{array}{l}\text { Sürükleyici } \\
\text { olma }\end{array}$ & Ö6 & 1 & \\
\hline & $\begin{array}{l}\text { Dersi daha iyi } \\
\text { dinleme }\end{array}$ & Ö1 & 1 & \\
\hline \multirow{6}{*}{ 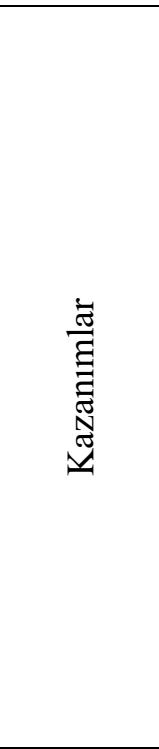 } & $\begin{array}{l}\text { Öğrenmeyi } \\
\text { pekiștirme }\end{array}$ & Ö5, Ö10 & 2 & \\
\hline & Kalıcilik & Ö3, Ö4 & 2 & \multirow{3}{*}{$\begin{array}{l}\text { Ö8. Kullanılan hikâyelerin öğrenmede etkisi çok çok } \\
\text { fazla. Çünkü hikâyeler bizde en azından bende } \\
\text { fazlasıyla merak uyandırdı. Acaba ne olacak? vs. diye. } \\
\text { İlgi çekiciydi. }\end{array}$} \\
\hline & $\begin{array}{l}\text { Kolay } \\
\text { anlaş1lma }\end{array}$ & Ö2 & 1 & \\
\hline & $\begin{array}{l}\text { Soru sorup } \\
\text { tartışma }\end{array}$ & Ö10 & 1 & \\
\hline & $\begin{array}{l}\text { Hizlı fikir } \\
\text { üreterek sonuca } \\
\text { ulaşma }\end{array}$ & Ö11 & 1 & $\begin{array}{l}\text { Ö10. Hikâye bence öğrenme açısından güzeldi. } \\
\text { Özellikle de soru sorulup tartışmamız hikâyeyi daha } \\
\text { öğrenilebilir kılıyor. Çünkü soru sorulan kısma kadar } \\
\text { hâkim olman gerekiyor tartışma için. }\end{array}$ \\
\hline & $\begin{array}{l}\text { Yaratıc1 } \\
\text { düşünceyi } \\
\text { geliştirme }\end{array}$ & Ö11 & 1 & $\begin{array}{l}\text { Ö11. Öğrencilerin yaratıcı düşüncelerini geliştirerek } \\
\text { bir konu hakkında fikir ortaya koymalarını sağlar. } \\
\text { Böylece öğrenciler karşılaştıkları herhangi bir } \\
\text { durumda hızlı bir şekilde fikir üreterek sonuca daha } \\
\text { kolay ulaşı1lır. }\end{array}$ \\
\hline
\end{tabular}

Tablo 5'te, öğretmen adaylarının hikâyelerin öğrenme üzerine etkisine yönelik cevaplarının motivasyon ve kazanımlar olmak üzere iki kategori altında toplandığı, öğrenme üzerine herhangi bir olumsuz etkisinin olacağına yönelik görüş bildirmedikleri görülmektedir. Motivasyon kategorisi altında, öğretmen adayları hikâyelerin merak uyandırması, dersi dinlemeyi să̆laması, ilgi çekici ve sürükleyici olması görüşlerinde birleşmektedirler. Kazanımlar kategorisi altında ise temel olarak öğrenme üzerine sağladığı olumlu etkinin yansımaları olarak kalıcı olma, kolay ve rahat anlaşılma, ögrenmeyi pekiştirme, yaratıcı düşünmeyi geliştirme gibi boyutlara yönelik olarak belirlenmiştir. 
Uygulamada kullanılan deneylerin size veya öğrenme-öğretme sürecine nasıl bir katkısı olduğunu düşünüyorsunuz? sorusuna verilen cevaplar Tablo 6' da sunulmuştur.

Tablo 6. Görüşme Formunun Dördüncü Sorusundan Elde Edilen Bulgular

\begin{tabular}{|c|c|c|c|c|}
\hline Kategori & Kod & $\begin{array}{l}\text { Öğretmen } \\
\text { adayı }\end{array}$ & f & Örnek cevap \\
\hline \multirow{3}{*}{ 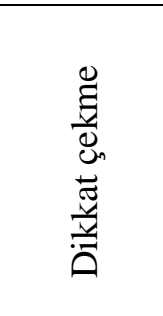 } & $\begin{array}{l}\text { Teorik bilgileri } \\
\text { görsel olarak } \\
\text { sunma }\end{array}$ & $\begin{array}{l}\text { Ö1, Ö2, Ö3, } \\
\text { Ö5, Ö6, Ö7, } \\
\text { Ö8, Ö9, Ö11 }\end{array}$ & 9 & \multirow{2}{*}{$\begin{array}{l}\text { Ö2. Hikâyede belirtilen durumların deneysel olarak da } \\
\text { gerçekleştirilmesi teorik bilginin nas1l gerçekleştiğini } \\
\text { bizzat görmemize imkân verdi. Böylelikle bilgi görsel } \\
\text { olarak da belleğimize işlenmiş oldu. }\end{array}$} \\
\hline & İlgi çekme & Ö3, Ö4 & 2 & \\
\hline & $\begin{array}{l}\text { Birden fazla } \\
\text { duyu organına } \\
\text { hitap etme }\end{array}$ & Ö11 & 1 & \multirow{4}{*}{$\begin{array}{l}\text { Ö6. Anlatılanı gözle görülür hale getirdik böylece } \\
\text { soyuttan somuta dönüştü bilgilerimiz ve daha kalıcı oldu. } \\
\text { Ö8. Deneyler her zaman konu öğrenmede etkili olmuştur. } \\
\text { İnsanın gördüğü bir şeyi aklına yerleştirmesi daha rahat } \\
\text { oluyor... }\end{array}$} \\
\hline \multirow{5}{*}{ 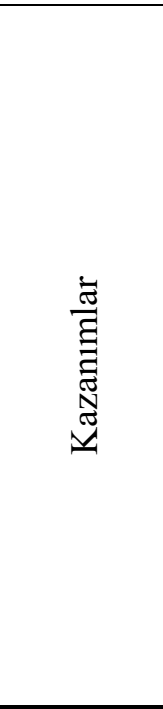 } & Kalıcılık & $\begin{array}{l}\text { Ö3, Ö5, Ö6, } \\
\text { Ö7, Ö10, } \\
\text { Ö11 }\end{array}$ & 6 & \\
\hline & $\begin{array}{l}\text { Öğrenme } \\
\text { üzerine olumlu } \\
\text { etki }\end{array}$ & Ö4, Ö5, Ö8 & 3 & \\
\hline & $\begin{array}{l}\text { Öğrenmeyi } \\
\text { pekiştirme }\end{array}$ & Ö9, Ö11 & 2 & \\
\hline & $\begin{array}{l}\text { Konunun } \\
\text { mantığını } \\
\text { kavrama }\end{array}$ & Ö8 & 1 & \multirow{2}{*}{$\begin{array}{l}\text { Ö10. Deneyler hikâyeyi desteklediği için } \\
\text { öğrendiklerimizin kalıcı olmasını sağladı. } \\
\text { Ö11. Bazen anlatılan konular yeterli gelmeyebilir. } \\
\text { Öğrenmeleri pekiştirmek için deneyler yapılmalı. } \\
\text { Konuları görsel açıdan zenginleştirerek ögrenmelerin } \\
\text { kalıcı olması sağlanır... Ne kadar fazla duyu organına } \\
\text { hitap edersek öğrenmeler o derece artar. }\end{array}$} \\
\hline & $\begin{array}{l}\text { Öğrencilerin } \\
\text { yeteneklerini } \\
\text { ortaya koyma }\end{array}$ & Ö11 & 1 & \\
\hline
\end{tabular}

Tablo 6'da deneylerin öğrenme üzerine etkisine yönelik olarak öğretmen adaylarının görüşlerinin dikkat çekme ve kazanımlar kategorileri altında toplandığı görülmektedir. $\mathrm{Bu}$ soruda da öğretmen adaylarının olumsuz görüş bildiren bir açıklama yapmadıkları belirlenmiştir. Dikkat çekme boyutunda teorik bilginin görsel olarak sunulması, ilgi çekici ve birden fazla duyu organına hitap etme kodları, kazanımlar boyutunda ise akılda kalıcılığ artırma, öğrenme üzerine olumlu etki, öğrenmeyi pekiştirme, konunun mantığını kavrama ve ögrencilerin yeteneklerini ortaya koyma kodları açı̆̆a çıkmıştır.

Uygulamada gerçekleştirilen tartışmaların size veya öğrenme-öğretme sürecine nasıl bir katkısı olduğunu düşünüyorsunuz? sorusuna verilen cevaplar Tablo 7'de sunulmuştur.

Tablo 7. Görüşme Formunun Beşinci Sorusundan Elde Edilen Bulgular

\begin{tabular}{|c|c|c|c|c|}
\hline Kategori & Kod & $\begin{array}{l}\text { Öğretmen } \\
\text { adayı }\end{array}$ & $\mathbf{f}$ & Örnek cevap \\
\hline $\begin{array}{l}\text { İletişim } \\
\text { süreçleri }\end{array}$ & $\begin{array}{l}\text { Farklı - ilginç } \\
\text { fikirlerin açı̆̆a } \\
\text { çıma }\end{array}$ & $\begin{array}{l}\text { Ö2, Ö3, Ö4, } \\
\text { Ö5, Ö6, Ö7, } \\
\text { Ö8, Ö9 }\end{array}$ & 8 & $\begin{array}{l}\text { Ö2. Farklı yorum ve fikirler, gelişime açık yorumlar } \\
\text { düşünceler doğuruyor. Doğruyu bulmak için fikir } \\
\text { yürütme }\end{array}$ \\
\hline
\end{tabular}




\begin{tabular}{|c|c|c|c|c|}
\hline & $\begin{array}{l}\text { Fikir - bilgi } \\
\text { alışverişi }\end{array}$ & $\begin{array}{l}\text { Ö1, Ö7, Ö8, } \\
\text { Ö9, Ö11 }\end{array}$ & 5 & Ö4. Sınıfta tartışmanın öğrenme üzerinde önemli bir \\
\hline & İletişim kurma & Ö11 & 1 & etkisi oldu. Çünkü farklı düşünceler çıkt1 \\
\hline & $\begin{array}{l}\text { Öğrencilerin } \\
\text { farklı fikirlerden } \\
\text { etkilenmesi }\end{array}$ & Ö1 & 1 & $\begin{array}{l}\text { arkadaşlardan. Bizim düşünmediğimiz fikirler. } \\
\text { Böylece bilgileri farklı görüşlerle sorguladık. }\end{array}$ \\
\hline \multirow{5}{*}{ 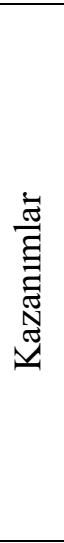 } & $\begin{array}{l}\text { Doğruya } \\
\text { ulaşmaya } \\
\text { yardımc1 } \\
\text { Ö̆ŏrenme }\end{array}$ & Ö2, Ö6, Ö8 & \multirow{6}{*}{\multicolumn{2}{|c|}{$\begin{array}{l}\text { Ö5. Farklı düşünce tarzları geliştirmek ve } \\
3 \text { öğrencilerin ufkunu açmak için düşünce yapılarını } \\
\text { ve hayal güçlerini geliştirmek ve değiştirmek için } \\
\text { oldukça etkili bir yöntemdir. } \\
33 \text { Ö7. Sınıftaki tartışmalarla uygulamaya yönelik } \\
\frac{2}{1} \text { fikirlerimizi sunmamız iyi oldu ve öğrenmeyi } \\
\text { kalıcılaştırdı. } \\
\text { Ö8. Sınıf içi tartışmalarda farklı ilginç fikirler } \\
1 \text { ortaya çıkabiliyor. Bir arkadaşımın söylediğiyle } \\
\text { kendi kafamdaki fikri sorgulayabiliyorum. Bazen } \\
\text { onunki daha mantıklı geliyor. Böylece doğruya } \\
1 \text { ulaşmış oluyoruz. }\end{array}$}} \\
\hline & $\begin{array}{l}\text { Öğrenme } \\
\text { üzerine olumlu } \\
\text { etki }\end{array}$ & Ö4, Ö5, Ö10 & & \\
\hline & Kalıcı bilgi & Ö7, Ö8 & & \\
\hline & $\begin{array}{l}\text { Sorunları daha } \\
\text { iyi anlama }\end{array}$ & Ö11 & & \\
\hline & $\begin{array}{l}\text { Çözüm } \\
\text { üretmeye } \\
\text { yardımc1 }\end{array}$ & Ö11 & & \\
\hline \multirow{4}{*}{ 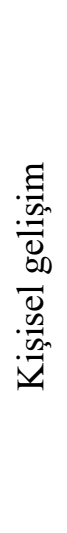 } & $\begin{array}{l}\text { Düşünce } \\
\text { yap1larını } \\
\text { geliştirme }\end{array}$ & Ö5 & & \\
\hline & $\begin{array}{l}\text { Kendini ifade } \\
\text { etme } \\
\text { yeteneğinin } \\
\text { gelişme }\end{array}$ & Ö11 & \multirow{3}{*}{\multicolumn{2}{|c|}{$\begin{array}{l}\text { Ö11. ...Tartışmalar sayesinde öğrencilerin kendini } \\
\text { ifade etme yetenekleri artar. Bu sayede kendine } \\
\text { güven duyguları gelişir. Birbirleri ile iletişime } \\
\text { girerler, bilgi alısverişi sayesinde yeni şeyler } \\
\text { - öğrenirler, bilgiden bilgi üretimi gerçekleşir. }\end{array}$}} \\
\hline & $\begin{array}{l}\text { Kendine güven } \\
\text { duygusunun } \\
\text { gelişme }\end{array}$ & Ö11 & & \\
\hline & $\begin{array}{l}\text { Hayal güçlerini } \\
\text { geliştirme }\end{array}$ & Ö5 & 1 & \\
\hline
\end{tabular}

Öğretmen adaylarının sınıf içi tartışmaların öğrenme üzerine etkisine yönelik cevaplarının iletişim süreçleri, kazanımlar ve kişisel gelişim olmak üzere üç kategori altında toplandığı, olumsuz fikirlerin yer aldığı açıklamaların ise bulunmadığı Tablo 7'de görülmektedir. İletişim süreçleri kategorisi altında fikir alışverişi, öğrencilerin birbirini etkilemesi ve gelişime açık yorumlar yer alırken kazanımlar kategorisi altında doğruya ulaşmada yardımcı olma, ögrenme üzerinde olumlu etki, çözüm üretmeye yardımcı ve öğrenilenlerin kalıcı olması görüşleri üzerinde durulduğu görülmektedir. Bunların dışında, kişisel gelişim kategorisi altında düşünce yapılarının, hayal gücünün, kendine güven ve kendini ifade yeteneğinin gelişmesine katkı sağlaması yönünde ifadelerin açığa çıktığı belirlenmiştir.

Sizce öğretim sürecinde kullanılan yöntemlerden herhangi biri olmasaydı süreç nasıl değişirdi? Her bir bileşen için ayrı ayrı fikirlerinizi belirtiniz? sorusuna verilen cevaplar Tablo 8'de sunulmuştur. 
Tablo 8. Görüşme Formunun Altıncı Sorusundan Elde Edilen Bulgular

\begin{tabular}{|c|c|c|c|c|}
\hline Kategori & Kod & $\begin{array}{l}\begin{array}{l}\text { Öğretmen } \\
\text { adayı }\end{array} \\
\end{array}$ & $\mathbf{f}$ & Örnek cevap \\
\hline \multirow{6}{*}{ 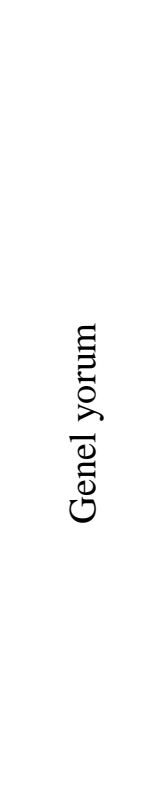 } & $\begin{array}{l}\text { Farklı öğrenme } \\
\text { stilleri }\end{array}$ & Ö11 & 1 & \multirow{3}{*}{$\begin{array}{l}\text { Ö4. Burada gerçekleştirdiğimiz etkinlik birbirini } \\
\text { takip eden bir sıra şeklinde ilerlediği için birinin eksik } \\
\text { olması demek eksik olandan sonraki etkinliklerin } \\
\text { anlaşılmasını zorlaştırır. Belki de hiç anlaşılmaz. } \\
\text { Ö5. Öğrenilen bilgiyi çeşitli öğretim yöntemleriyle } \\
\text { pekiştirmek ve kalıcı hale getirmek oldukça } \\
\text { önemlidir. Yöntemlerden biri eksik olduğunda kalıcı } \\
\text { öğrenme gerçekleşmeyebilir. }\end{array}$} \\
\hline & $\begin{array}{l}\text { Aktif katılımı } \\
\text { sağlama }\end{array}$ & Ö11 & 1 & \\
\hline & Kalıcılik & Ö5, Ö11 & 2 & \\
\hline & $\begin{array}{l}\text { Tamamlayıcı } \\
\text { bileşenler }\end{array}$ & $\begin{array}{l}\text { Ö1, Ö3, Ö4, } \\
\text { Ö5, Ö7, Ö10 }\end{array}$ & 6 & \multirow{3}{*}{$\begin{array}{l}\text { Ö7.Üçü de birbirinin tamamlayıcısı görevini } \\
\text { üstlendiği için birinin eksikliği bile ögrenmeyi } \\
\text { olumsuz etkileyebilir } \\
\text { Ö11. Her bir öğrencinin öğrenme stili farklı } \\
\text { olduğundan farklı yöntemleri derste kullanmak } \\
\text { gerekir. Bu yöntemler olmasaydı ögrencilerin derse } \\
\text { katılımı azalır ve öğrenmeler kalıcı olmazdı. }\end{array}$} \\
\hline & $\begin{array}{l}\text { Bilgiyi } \\
\text { pekiştirme }\end{array}$ & Ö5 & 1 & \\
\hline & Kolay öğrenme & Ö4 & 1 & \\
\hline
\end{tabular}

\begin{tabular}{|c|c|c|c|c|}
\hline \multirow{9}{*}{ 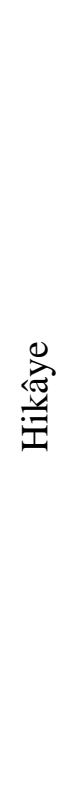 } & Yaratıcı fikir & Ö11 & 1 & \multirow{3}{*}{$\begin{array}{l}\text { Ö2. ...Hikâyeler olmasaydı aradaki tartışmalar da } \\
\text { olmazdı. Yapılan deneyin ne olduğunu neye } \\
\text { yaradığını anlamazdık. }\end{array}$} \\
\hline & Kalıcılık & Ö8, Ö11 & 2 & \\
\hline & Hayal gücü & Ö11 & 1 & \\
\hline & $\begin{array}{l}\text { Tartışmayı } \\
\text { destekleme }\end{array}$ & Ö2, Ö6, Ö10 & 3 & \multirow{3}{*}{$\begin{array}{l}\text { Ö7. Dikkat çekti, merak uyandırdı ve öğrenmenin } \\
\text { olumlu yönde seyrine olanak sağladı. } \\
\text { Ö9. Belki bu kadar dikkatli dinleyip merak etmezdik. }\end{array}$} \\
\hline & $\begin{array}{l}\text { Merak } \\
\text { uyandırma }\end{array}$ & Ö7, Ö9 & 2 & \\
\hline & Dikkat çekme & Ö7, Ö8, Ö9 & 3 & \\
\hline & $\begin{array}{l}\text { Öğrenmeyi } \\
\text { destekleme }\end{array}$ & Ö7 & 1 & \multirow{3}{*}{$\begin{array}{l}\text { Ö11. Konu hakkında yaratıcı fikirlerini } \\
\text { söyleyemeyecek bu da kalıc1 öğrenmelerin } \\
\text { oluşmasını engelleyecekti. Öğrencilerin hayal } \\
\text { dünyasını kısıtlayacaktı. }\end{array}$} \\
\hline & $\begin{array}{l}\text { Sürükleyici } \\
\text { olma }\end{array}$ & Ö6 & 1 & \\
\hline & $\begin{array}{l}\text { Deneyi } \\
\text { destekleme }\end{array}$ & Ö2 & 1 & \\
\hline \multirow{5}{*}{ 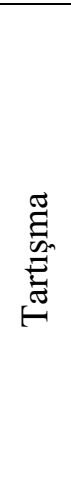 } & $\begin{array}{l}\text { Fikirlerini } \\
\text { özgürce } \\
\text { savunma }\end{array}$ & Ö11 & 1 & \multirow{5}{*}{$\begin{array}{l}\text { Ö2. Yeni fikir, düşünce ve yorumlar olmazdı. } \\
\text { Ö7. Bir düşüncemizi oluşturmak için çaba } \\
\text { harcamayacaktık veya kalıcı olmayacaktı. } \\
\text { Ö8. Sınıf içi tartışmalar olmasaydı sınav gibi bir şey } \\
\text { olurdu. Kendi düşündüğümle kalırdım. Ama } \\
\text { arkadaşlarım fikirlerini söyledikçe kafamda bir şeyler } \\
\text { değişti veya yeni fikirler elde ettim. Olmazsa olmaz. }\end{array}$} \\
\hline & $\begin{array}{l}\text { Özgüveni } \\
\text { geliştirme }\end{array}$ & Ö11 & 1 & \\
\hline & $\begin{array}{l}\text { Farklı bakış } \\
\text { aç1larını görme }\end{array}$ & Ö8, Ö9, Ö10 & 3 & \\
\hline & $\begin{array}{l}\text { Hikâyeyi } \\
\text { destekleme }\end{array}$ & Ö10 & 1 & \\
\hline & $\begin{array}{l}\text { Yeni fikirler } \\
\text { oluşturma }\end{array}$ & Ö2, Ö8 & 2 & \\
\hline
\end{tabular}




\begin{tabular}{|c|c|c|c|c|}
\hline & $\begin{array}{l}\text { Düşünmeye } \\
\text { sevk etme }\end{array}$ & $\begin{array}{l}\text { Ö7 } \\
\text { Ö6 }\end{array}$ & 1 & $\begin{array}{l}\text { Ö11. Öğrenciler özgürce fikirlerini savunamazd1. Bu } \\
\text { da öğrencilere güven duygusunun oluşmasına engel } \\
\text { olurdu. }\end{array}$ \\
\hline \multirow{4}{*}{ 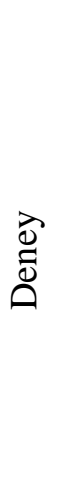 } & $\begin{array}{l}\text { Öğrenmeyi } \\
\text { destekleme }\end{array}$ & $\begin{array}{l}\text { Ö9, Ö10, } \\
\text { Ö11 }\end{array}$ & 3 & \multirow{3}{*}{$\begin{array}{l}\text { Ö2. En son düzeneğin nasıl işlediğini anlayamazdık. } \\
\text { Ö7. Kalıcı olmazdı ve teorik olarak kalacaktı. } \\
\text { Ö8. ...Deneyleri bilmeyen biri için tabi ki önemli. } \\
\text { Konuyu mantığa sığdırmak açısından da çok önemli } \\
\text { bir basamak kalıcılığı arttırıyor... }\end{array}$} \\
\hline & $\begin{array}{l}\text { Yaparak } \\
\text { yaşayarak } \\
\text { ögrenme } \\
\end{array}$ & $\begin{array}{l}\text { Ö2, Ö7, Ö9, } \\
\text { Ö11 }\end{array}$ & 4 & \\
\hline & $\begin{array}{l}\text { Konuya } \\
\text { kavrama }\end{array}$ & Ö2, Ö6, Ö8 & 3 & \\
\hline & Kalıcılık & Ö7, Ö8 & 2 & $\begin{array}{l}\text { Ö11. Anlatılan konular anlaşılamayabilirdi. Deneyler } \\
\text { öğrencilere görerek yaparak öğrenme fırsatı } \\
\text { sağlamaktadır. }\end{array}$ \\
\hline
\end{tabular}

Tablo 8'den görüldüğü gibi, uygulamada kullanılan hikâye, tartışma ve deney bileşenleri arasındaki ilişkiye yönelik olarak öğretmen adaylarının verdikleri cevaplar genel yorum, hikâye, tartışma ve deney kategorileri altında sınıflandırılmıştır. Genel yorum kategorisinde öğretmen adayları her bir bileşenin birbirinin tamamlayıcısı olduğunu, bunlardan birinin eksik olmasının sürecin etkililiğini azaltacă̆ını ve öğrenmenin istenilen şekilde gerçekleşmesinin zorlaşacă̆ını ifade etmişlerdir. Hikâye kategorisinde, öğretmen adaylarının görüşlerinin merak uyandırma, ilgi çekme ve dersin daha akıcı biçimde işlenmesine katkı sağlama gibi olumlu etkiler üzerine odaklandıkları görülürken, hikâyelerin süreçte kullanılmaması durumunda tartışmaların yapılamayacă̆l, konu hakkında öğrencilerin fikirlerini paylaşamayacă̆l, hayal dünyalarının kısıtlanacağl ve kalıcı ögrenmelerin oluşmasının engelleneceği görüşlerinin açığa çıktığı tespit edilmiştir. Öğretmen adaylarının tartışma kategorisinde yer alan görüşlerine bakıldığında, tartışmaların olmaması durumunda yeni fikir, düşünce ve yorumların paylaşılamayacağı, tek bir açıdan bakıp konunun farklı yönlerinin görülememesi, düşüncelerin oluşturulması için çaba harcanmayacă̆ ve kalıcı öğrenmelerin olmayacağını ifade ettikleri görülmektedir. Ayrıca, öğrencilerin fikirlerini özgürce savunamaması ve güven duygularının oluşmaması da sınıf tartışmalarının olmaması durumuna yönelik görüşler arasında yer almaktadır. Deney kategorisinde ise, deneylerin olmaması durumunda, bilgilerin teorik olarak ya da ögrencinin zihninde canlandırdiğı haliyle kalacă̆l, konunun yeterince anlaşılmaması ve kalıcı olmaması ile ilgili görüşlerin olduğu belirlenmiştir.

\section{Tartışma}

Bilim tarihi temelli hikâyelerle fen öğretiminin gerçekleştirilmesine yönelik örnek bir uygulama olması amacıyla gerçekleştirilen bu çalışmada, öğretmen adaylarının hikâyelere ve öğretim sürecine yönelik olumlu görüşlere sahip oldukları görülmüştür. Bilim tarihi temelli hikayeler 
odağında tasarlanan öğretim sürecinde, öğretmen adaylarının konuya yönelik ilgi ve motivasyonlarının artması ve sürece aktif olarak katılmaları, onların hikayelerdeki karakterlerle empati kurmalarının ve içerikte verilen durumları içselleştirerek kendi düşüncelerini ifade etmeye yönelik olarak cesaretlenmelerinin bir sonucu olarak kabul edilebilir. Kahraman (2012) tarafından yedinci sınıf öğrencilerinin kuvvet ve hareket ünitesi kavramlarını öğrenmeleri üzerine bilim tarihi temelli hikayelerin etkisini araştırmak amacıyla yürütülen çalışmada, öğrencilerin hikayelerde yer alan karakterlerle empati kurmalarının onların hikayeye dolayısıyla da konu ve kavramlara olan ilgi ve meraklarını artırdığı ifade edilmektedir. Bu sayede, hedeflendiği biçimde açığa çıkan tartışma ortamları aracılığıyla gerçekleşen etkileşimlerin, öğretmen adaylarının bilimsel ilerlemelerin bir bakıma sosyal boyutta da ne şekilde gerçekleştiğine yönelik fikir edinmelerine yardımcı olduğu söylenebilir (Güney ve Şeker, 2012). Bu doğrultuda literatürde de öğrencilerin herhangi bir konuya yönelik öğrenme sürecinde teorik bilgilerin yanı sıra o bilginin ya da buluşun tarihsel olarak ortaya çıkma ve gelişme sürecini öğrendiklerinde konuya daha fazla ilgi ve merak duydukları ifade edilmektedir (Matthews, 2009; Yavuzoğlu, 2018). Benzer şekilde, hikâyede yer alan ve tartışmalar kapsamında inceledikleri durumlar ve savundukları görüşlere yönelik deneyler aracılığıyla uygulama yapma firsatı bulan öğretmen adaylarının görüşlerini bilimsel kanıtlarla desteklemesi, sürece yönelik motivasyonlarını yükseltmiştir. Bu sürecin aynı zamanda onların bilim insanlarının çalışmalarının hangi veriler ve araçlarla, ne gibi koşullar altında ortaya çıkarıldığına yönelik olarak da fikir edinmelerini desteklediği düşünülmektedir. Tüm bu bileşenlerin öğretmen adaylarının ilgi ve motivasyonları üzerindeki olumlu etkileri göz önünde bulundurulduğunda, bilim tarihi temelli hikayeler aracılı̆̆ıyla gerçekleştirilen öğretim uygulamalarının fen konularına ve bilim tarihine yönelik pozitif tutum geliştirmeyi desteklemede önemli bir role sahip olduğu ifade edilebilir (Kaya, 2007; Matthews, 1994; Seker, 2004; Wandersee, 1995).

Görüşme formlarından elde edilen verilere bakıldığında, öğretmen adaylarının LES modeline göre gerçekleştirilen bu uygulamanın tüm aşamalarını kapsamakla beraber özellikle girme (launch) aşamasında ilgi çekici, sürükleyici ve merak uyandırıcı nitelikte olmasıyla ilgili görüşlere sahiptirler (Tablo 3, Tablo 8). Benzer şekilde, öğrenmeyi pekiştirdiği, kalıcılığı sağladığı, tartışma ortamını güdülediği ve yaratıcı düşünmeyi desteklediği öğretmen adayları tarafından vurgulanmıştır. Girme (launch) aşamasının, hikayenin kurgusunun tanıtılması, ana karakterin bir problemle karşılaması ve bu probleme çözüm bulma çabasını içermesi öğretmen adaylarında merak uyandırdığı düşünülmektedir. Öğrencilerin derse yönelik ilgisini ve 
motivasyonunu artırmanın öğretmenlik mesleğinin en önemli ve dikkat gerektiren boyutlarından biri olduğu düşünüldüğünde öğretmen adaylarının kendi katıldıkları öğretim uygulamalarında da bu hususlara dikkat etmeleri mesleki gelişime yönelik farkındalıklarının bir göstergesi olarak kabul edilebilir. Bu noktada, öğretmen adaylarının LES modeli ile bilim tarihi temelinde gerçekleştirilen öğretim uygulamalarının öğrencilerin ilgileri ve motivasyonları üzerindeki olumlu etkisini özellikle vurgulamaktadırlar (Dincel, 2005; Kahraman ve Karataş, 2009; Kaya, 2007; Klassen, 2009; Roach ve Wandersee, 1995; Seker, 2004; Yücel, 2009). Keşfetme (explore) aşamasında ana karakterin yaşadığı problemin çözümü için yürütülen deneylerin, hikayenin akışında bilimsel gelişim sürecinin bir parçası olarak kabul edilmesiyle öğretmen adaylarının bağımsız bir deneyden daha fazla dikkatini çektiği düşünülmektedir. Bu şekilde, ortaya koyulan problemlerin çözümünün de zihinlerinde kalıcı olmasının desteklendiği ifade edilebilir (Tablo 6, Tablo 8). Yürütülen çalışmada, öğretmen adaylarının önce problemi çözmeye yönelik kendi deneylerini tasarlamaları ve tasarımları üzerine tartışmalarının daha sonra hikayeye devam ederek problemin çözümünü içeren deney düzeneğini kurmalarının kalıcılığın sağlanmasında etkili olduğu düşünülmektedir. Reçete gibi izlenecek adımların sıralı şekilde yazılı olduğu deneyler yerine öğretmen adaylarının kendi deneylerini tasarlayarak kendi tasarılarını uygulaması daha anlamlı olmasının yanı sıra (Hofstein ve Lunetta, 1982), adayların probleme yönelik kendi çözümleri ile ana karakterin çözümünü karşılaştırma firsatı bulmaları kendi bakış açılarındaki hataları görmeleri ve anlamlı öğrenme açısından önemlidir. Ayrıca, öğretmen adayları bu tür uygulamalar aracılığıyla öğrencilerin problemi anlama ve çözüm üretme becerisi kazanabileceklerini düşündüklerini ifade etmişlerdir. Bunların yanı sıra, öğretmenin aktif olduğu ve geleneksel öğretimin gerçekleştirildiği sınıflardan gelen öğretmen adaylarının, bu tür uygulamaların etkili öğrenme ortamlarının sağlanması için gerekli olduğunu düşünmeleri geçmişteki olumsuz öğrenme yaşantıları ve mesleğe yönelik idealist bir tutum geliştirmeleriyle ilgili olabilir. Bu bağlamda, bilim tarihi temelli hikayelerle gerçekleştirilen uygulamaların deneysel süreçler içermesi öğrenenin ilgi ve motivasyonu artırmasının yanı sıra problem çözme ve eleştirel düşünme becerilerinin geliştirilmesine de olanak sağlayacak niteliktedir (Klassen, 2007; Kokkotas ve diğ., 2010). Bu bağlamda, öğretmen adaylarının 21. yüzyıl becerilerinin gerektirdiklerinin farkında oldukları ve bu yönde gerçekleştirilecek uygulamaların değerinin farkına vardıkları söylenebilir. Özellikle LES modeli ile yürütülen uygulama sürecinin özetleme (summarize) aşamasında daha baskın olmakla birlikte öğretimin tamamına yayılan tartışma ortamına yönelik görüşlere bakıldığında (Tablo 7, Tablo 8), öğretmen adaylarının bilimsel görüşler üzerine 
iletişim kurma, fikir alışverişi yapmanın önemi ve fikrini savunmayı öğrenme ve savunma fırsatı bulmanın öğrenme üzerindeki etkisine yönelik görüşlere sahip olmaları, onların öğrenmenin sosyal etkileşim bağlamında ve demokratik ortamlarda gerçekleşmesi gereken bir süreç olduğunu düşünmelerinin bir sonucu olarak ortaya çıkmış olabilir. Hikâyelerle yürütülen öğretimin, öğrenme ortamını öğrencilerin birey olarak düşüncelerini savunmalarına olanak vermesi, öğrenci-öğrenci(ler) ve öğrenci(ler)-öğretmen arasındaki iletişimi arttırarak sınıf ortamını geleneksel süreçlerden ve formal ilişkilerden uzaklaştırmaya katkı sağladığı ifade edilebilir (Güney ve Bakanay, 2018; Kokkotas ve diğ., 2010; Manna ve Minichiello, 2005). Hikayelerle öğretim sürecinde, öğrenenler hikaye ilerledikçe, hikayenin bir parçası olarak kavramları keşfeder, önceki bilgilerini ve deneyimlerini kullanabilecekleri durumlarla karşılaşır ve bunlar üzerine sorular sorarak tartışma firsatı bulurlar (Isabelle, 2007). Bu tür öğretim süreçlerinde seçilen öğretim yönteminin de öğrenenlerin soru sormalarına, tartışmalarına, denemeler yapmalarına, bilimsel bilginin anlaşılmasını kolaylaştırma gibi fırsat vermesinin önemli olduğu düşünülmektedir. Öğretmen adaylarının görüşlerinde, çalışmada kullanılan LES modelinin adaylara bu tür olanaklar sunarak elektrik konularının öğretilmesinde sorgulamaya dayalı etkili bir yöntem olduğu ortaya çıkmaktadır.

Bilim tarihi temelli hikayelerin LES modeli ile bütünleştirildiği öğrenme ortamına yönelik sadece öğrenen konumunda değil aynı zamanda mesleğe hazırlanan öğreticiler konumunda da bulunan adaylar tarafindan ortaya konan olumlu görüşlerin, bu tür uygulamaların hem kavramsal hem de mesleki gelişim için oldukça etkili sonuçlar elde etmeyi destekleyeceği düşünülmektedir. Bilim tarihi temelli hikayelerin deneysel, problem veya proje tabanlı öğretim süreçlerine kolayca adapte edilebilir olmasının (Topdemir ve Unat, 2014), bu çalışmada da öğretmen adaylarının öğrenmelerin yanı sıra bu kolaylıkları da gözlemlemelerinin bu çalışmayla mesleki gelişimlerinin desteklenmesinin sağlandığı şeklinde yorumlanabilir. $\mathrm{Bu}$ bağlamda, hikâyelerin aktif öğrenme ortamlarının tasarlanması ve hayal gücü ve yaratıcılık gibi 21. yüzyıl becerileri çerçevesinde ifade edilen becerilerin geliştirilmesi için etkili bir araç olduğu ifade edilebilir. Ayrıca, bilim tarihi temelli hikâyelerin, öğrenmenin pekiştirilmesi ve kalıcı öğrenmelerin sağlanmasına katkı sağlayacak öğrenme ortamları için gerekli niteliklere sahip olduğu düşünülmektedir (Hidi, Renninger ve Krapp, 2004). Dolayısıyla, öğrencilerin fen derslerine olan ilgilerinin artırılması, entelektüel gelişimlerinin desteklenmesi (Klassen ve Froese-Klassen, 2014), sorgulama ve görünenin ötesindeki bilgi ve anlamları fark ederek yorumlama becerilerinin artırılması (Krapp, 1999) ve bilişsel gelişimlerini destekleyerek kalıcı 
öğrenmelerin sağlanmasında (Hidi ve diğ., 2004) bilim tarihi temelli hikâyelerin etkili olduğu kabul edilmektedir.

\section{Sonuçlar ve Öneriler}

Bilim tarihi temelli hikayeler aracılığıyla gerçekleştirilen bu uygulamada, öğretmen adaylarının hikayeler üzerinden karakterler ile empati kurma ve bilimsel sorunlara yönelik eleştirel bir bakış açısıyla yaklaşma ve sınıf içi tartışmalar aracılığıyla görüşlerini ifade etme, gerekli durumlarda savunma ya da farklı görüşlere yönelme eğilimi gösterme firsatı buldukları belirlenmiştir. $\mathrm{Bu}$ bağlamda, bu tür öğretim uygulamalarının sosyal öğrenme ve bilimsel iletişim süreçlerine katılımı sağlamada etkili olduğu sonucuna ulaşılmıştır. Bu noktada, fen öğretiminin ezbere ve formüllere dayalı bir bilimin bileșenlerini öğrenmek ve öğretmenin ötesinde, sosyal bağlamda kişiler arası iletişim yoluyla da gerçekleştirilmesi gerektiği düşünülmektedir. Fen öğretiminin etkili iletişim ortamlarının sağlandığı uygulamalar aracılığıyla gerçekleştirilmesinin öğrenenlerin bilimsel iletişim kurma becerileri üzerine olumlu etkilerinin olacağı da düşünülmektedir.

Gerçekleştirilen öğretim uygulaması sonucunda, bilim tarihi temelli hikâyelerin LES modeli ile birlikte kullanılmasının etkili öğrenme ortamı sağladığı öğretmen adaylarının görüşme formundaki sorulara verdikleri cevaplarda belirlenmiştir. $\mathrm{Bu}$ bağlamda, etkili öğretim uygulamalarının yapılabilmesi için öğretmen adaylarına yeni öğretim yöntemlerine yönelik bilgi verilmesinin ve uygulamalar yapılmasının gerekli olduğu düşünülmektedir. Bu nedenle, bilim tarihi temelli hikayelerin ve LES modelinin eğitim fakültelerinde öğretmen adaylarına ve hizmet içi kurslarla öğretmenlere tanıtılması önerilmektedir.

Öğrenci merkezli öğretim uygulamalarının öneminin yoğun biçimde ifade edildiği göz önünde bulundurulduğunda bilim tarihi temelli hikâyelerle yürütülecek öğretim uygulamalarının öğrenenlerin fen kavramlarını anlamalarına destekleyecek öğrenme ortamları sunacağı düşünülmektedir. Bilim tarihi temelli hikâyelerle öğrenenlere konu ve kavramların öğretilmesinin yanı sıra bilim insanlarının hayatları ve bilimsel çalışmaların tarihsel gelişimi de sunulabilmektedir. Bu nedenle, diğer öğretim kademelerinde ve fen konularında da bilim tarihi temelli hikâyelerinin yazılması ve buna yönelik öğretim uygulamalarının tasarlanmasının alana katkı sağlayacağı düşünülmektedir.

\section{Makalenin Bilimdeki Konumu}

Matematik ve Fen Bilimleri Eğitimi / Fen Bilgisi Eğitimi 


\section{Makalenin Bilimdeki Özgünlüğü}

Çalışmada, fen bilgisi öğretmen adaylarına yönelik LES modeli doğrultusunda belirlenen iki elektrik konusuyla ilgili bilim tarihi temelli hikayeleri içeren öğretim süreci tasarlanmıştır. Öğretmen adaylarının bu tür süreçler içerisinde yer almaları onların hem bilim doğasına yönelik farkındalıklarını artırmakta hem de onları bilim tarihi temelli hikayeleri kendi öğretim süreçlerine katmaya teşvik etmektedir. Öğretim süreci ile birlikte öğretmen adayları, kendileri için yeni bir öğretim yaklaşımı olan LES modeli hakkında da bilgi sahibi olmuşlardır. Çalışma, sadece hikayeleri değil tartışma ve deney teknikleri gibi öğretim unsurlarını içerecek şekilde tasarlanmasıyla literatürdeki çalışmalardan ayrılmaktadır. Küçük bir grupla yürütülen bu uygulamada, fen bilgisi öğretmen adaylarının bilim tarihi temelli hikayeleri farklı tekniklerle beraber kullanmaya istekli olmaları, hikayelerin LES modeliyle birlikte kullanılmasının etkin öğretim ortamları tasarlanmasına katkı sağladığı inancını oluşturmaktadır.

\section{Kaynaklar}

Abd-El-Khalick, F., \& BouJaoude, S. (1997). An exploratory study of the knowledge base for science teaching. Journal of Research in Science Teaching: The Official Journal of the National Association for Research in Science Teaching, 34(7), 673-699.

Abd-el-Khalick, F. (1999). Teaching science with history. The Science Teacher, 66(9), 18-22.

Akerson, V. L., Abd-El-Khalick, F., \& Lederman, N. G. (2000). Influence of a reflective explicit activity-based approach on elementary teachers' conceptions of nature of science. Journal of Research in Science Teaching: The Official Journal of the National Association for Research in Science Teaching, 37(4), 295-317.

Banister, F., \& Ryan, C. (2001). Developing science concepts through story-telling. School Science Review, 82, 75-84.

Bertiz, H. (2005). Fen bilgisi ögretmen adaylarının yaratıcı dramaya yönelik tutumları ve öyküleme çalışmalarına ilişkin görüşleri (Yayımlanmamış yüksek lisans tezi). Abant İzzet Baysal Üniversitesi, Sosyal Bilimler Enstitüsü, Bolu.

Brito, A., Rodriguez, M. A., \& Niaz, M. (2005). A reconstruction of development of the periodic table based on history and philosophy of science and its implications for general chemistry textbooks. Journal of Research in Science Teaching: The Official Journal of the National Association for Research in Science Teaching, 42(1), 84-111.

Brush, S. G. (1974). Should the history of science be rated X?. Science, 183(4130), 1164-1172.

Brush, S. G. (1989). History of science \& science education. Interchange, 20(2), 60-70. 
Clough, M. P. (2006). Learners' responses to the demands of conceptual change: Considerations for effective nature of science instruction. Science and Education, 15(5), 463-494.

Clough, M. P. (2010). The story behind the science: Bringing science and scientists to life in post-secondary science education. Science \& Education, 20(7-8), 701-717.

Çepni, S., ve Keleş, E. (2006). Turkisch students' conceptions about the simple electric circuits. International Journal of Science and Mathematics Education, 4, 269-291.

Demirci, N., ve Çirkinoğlu, A. (2004). Öğrencilerin elektrik ve manyetizma konularında sahip oldukları ön bilgi ve kavram yanılgılarının belirlenmesi. Türk Fen Eğitimi Dergisi, 1(2), 116-138.

Demircioğlu, H. (2008). Sınıf ögretmeni adaylarına yönelik maddenin halleri konusuyla ilgili bağlam temelli materyal geliştirilmesi ve etkililiğinin araştırılması (Yayımlanmamış doktora tezi). Karadeniz Teknik Üniversitesi, Fen bilimleri Enstitüsü, Trabzon.

Demircioğlu, H., Ayas, A., Demircioğlu, G., \& Özmen, H. (2015). Effects of storylines embedded within the context-based approach on pre-service primary school teachers' conceptions of matter and its states. Asia-Pacific Forum on Science Learning and Teaching. 16(2), 1-30.

Demircioğlu, H., Demircioğlu, G., \& Çalik, M. (2009). Investigating the effectiveness of storylines embedded within a context-based approach: The case for the Periodic Table. Chemistry Education Research and Practice, 10(3), 241-249.

Dilber, B., \& Düzgün, B. (2008). Effectiveness of analogy on students’ success and elimination of misconceptions. Latin American Journal of Physics Education, 2(3), 174-183.

Dincel, M. (2005). Öyküleme ve deney tekniğinin fen bilgisi dersinde ögrrencilerin kavramsal anlama ve başarılarına etkisi (Yayımlanmamış yüksek lisans tezi). Marmara Üniversitesi, Eğitim Bilimleri Enstitüsü, İstanbul.

Duit, R., \& Rhöneck, C. (1997). Learning and understanding key concepts of electricity. In A. Tiberghien, E. L. Jossem \& J. Barojas (Eds.) Connecting research in physics education with teacher education (pp.1-6). The International Commission on Physics Education.

Eichinger, D. C., Abell, S. K., \& Dagher, Z. R. (1997). Developing a graduate level science education course on the nature of science. Science and Education, 6(4), 417-429.

Ersoy, A., ve Papatğa, E. (2015). İlkokul öğrencilerinin hikâyeler aracılığıyla bilinçli tüketici farkındalığının geliştirilmesi. Eğitimde Politika Analizi, 4(1), 61-78. 
Faikhamta, C. (2013). The development of in-service science teachers' understandings of \& orientations to teaching the nature of science within a PCK-based NOS course. Research in Science Education, 43(2), 847-869.

Finger, S., Piccolino, M., \& Stahnisch, F. W. (2013a) Alexander von Humboldt: Galvanism, animal electricity, and self-experimentation part 1: Formative years, naturphilosophie, and Galvanism. Journal of the History of the Neurosciences, 22(3), 225-260.

Finger, S., Piccolino, M., \& Stahnisch, F. W. (2013b) Alexander von Humboldt: Galvanism, animal electricity, and self-experimentation part 1: The electric eel, animal electricity, and later years. Journal of the History of the Neurosciences, 22(4), 327-352.

Guney, B. G., \& Seker, H. (2012). The use of history of science as a cultural tool to promote students' empathy with the culture of science. Educational Sciences: Theory \& Practice, 12(1), 533-539.

Güney, B. G., \& Bakanay, Ç. D. (2018). Öğretmen adaylarının bilim tarihi tabanlı ders deneyimleri. Bilim Ĕgitim Sanat ve Teknoloji Dergisi, 2(1), 40-51.

Hidi, S., Renninger, K. A., \& Krapp, A. (2004). Interest, a motivational variable that combines affective \& cognitive functioning. In D. Y. Dai ve R. J. Sternberg (Eds.), Motivation, emotion, \& cognition: Integrative perspectives on intellectual functioning \& development (pp. 89-115). Mahwah, NJ: Lawrence Erlbaum Associates.

Hofstein, A. \& Lunetta, N. V. (1982). The role of the laboratory in science teaching: neglected aspects of research. Review of Educational Research, 52(2), 210-217.

Horton, J. (2013). Teaching science through story. Teaching Science, 59(3), 38-41.

Howe, A., \& Johnson, J. (1992). Common bonds storytelling in the classroom. London: HveS. Isabelle, A. (2007). Teaching science using stories: The storyline approach. Science Scope, 31(2), 16-25.

Justi, R., \& Gilbert, J. (2000). History \& philosophy of science through models: Some challenges in the case of 'the atom'. International Journal of Science Education, 22(9), 993-1009.

Kahraman, F. (2012). Bilim tarihi temelli hikayelerin ilköğretim 7. sinıf ögrencilerinin "kuvvet ve hareket" ünitesi kavramlarını anlama düzeylerine etkisi (Yayımlanmamış yüksek lisans tezi). Karedeniz Teknik Üniversitesi, Eğitim Bilimleri Enstitüsü, Trabzon.

Kahraman, F., \& Karataş, F. Ö. (2015). Story telling: Research \& action to improve 6 th grade students' views about certain aspects of nature of science. Asia-Pacific Forum on Science Learning and Teaching, 16(1), 1-25. 
Kaya, A. (2007). Fen ĕgitiminde bilim tarihi destekli öğretimin fen bilgisi öğretmen adaylarının bilim doğasına ilişkin görüşlerine etkisinin değerlendirilmesi (Yayımlanmamış yüksek lisans tezi). Balıkesir Üniversitesi, Fen Bilimleri Enstitüsü, Balıkesir.

Klassen, S. (2007). The application of historical narrative in science learning: The Atlantic cable story. Science and Education, 16(3-5), 335-352.

Klassen, S. (2009). The construction \& analysis of a science story. Science and Education, 18, 401-423.

Klassen, C. F. (2014). A methodology for analyzing science stories. Interchange, 45(3-4), 153165.

Klassen, S., \& Froese-Klassen, C. (2014). Science teaching with historically based stories: Theoretical \& practical perspectives. In M. R. Matthews (Eds.) International handbook of research in history, philosophy \& science teaching (pp. 1503-1529). Springer, Dordrecht.

Kokkotas, P., Rizaki, A., \& Malamitsa, K. (2010). Storytelling as a strategy for understanding concepts of electricity \& electromagnetism. Interchange, 41(4), 379-405.

Koştur, H. İ. (2017). FeTeMM eğitiminde bilim tarihi uygulamaları: El-Cezeri örneği. Başkent University Journal of Education, 4(1), 61-73.

Krapp, A. (1999). Interest, motivation \& learning: An educational-psychological perspective. European Journal of Psychology of Education, 14(1), 23-40.

Küçük, M. (2006). Bilimin doğasını ilköğretim 7. sınıf ögrrencilerine ögrretmeye yönelik bir çalışma (Yayımlanmamış doktora tezi). Karadeniz Teknik Üniversitesi, Fen Bilimleri Enstitüsü, Trabzon.

Laçin-Şimşek, C. (2009). Fen ve teknoloji dersi öğretim programları ve kitapları bilim tarihinden ne kadar ve nasıl yararlanıyor?. Ilköğretim Online, 8(1), 129-145.

Laçin-Şimşek, C. (2011). Science \& technology teachers' situation of integrating history of science into their lessons. International Online Journal of Educational Sciences, 3(2), 707-742.

Lederman, N. G. (1992). Students' \& teachers' conceptions of the nature of science: A review of the research. Journal of Research in Science Teaching, 29(4), 331-359.

Lederman, N. G. (1998). The state of science education: Subject matter without context. Electronic Journal of Science Education, 3(2), 1-6. 
Lin, H. S., \& Chen, C. C. (2002). Promoting preservice chemistry teachers' understanding about the nature of science through history. Journal of Research in Science Teaching, 39(9), 773-792.

Manna, C., \& Minichiello, G. (2005). Imagination without images. Teaching Education, 16(1), 51-60.

Martin, T. C. (1894). The inventions, researches and writings of Nikola Tesla. D. Van Nostrand Company, New York.

Matthews, M. R. (1994). Science teaching: The role of history \& philosophy of science. Routledge, New York.

Matthews, M. R. (Ed.). (2009). Science, worldviews and education. New York: Springer.

McDonald, C. V. (2010). The influence of explicit nature of science \& argumentation instruction on preservice primary teachers' views of nature of science. Journal of Research in Science Teaching, 47(9), 1137-1164.

McComas, W. F., \& Olson, J. K. (2000). The nature of science in international science education standards documents. In W. F. McComas (Ed.) The nature of science in science education rationales \& strategies (pp. 41-52). The Netherlands: Kluwer Academic Publishers.

Mihladız, G., \& Doğan, A. (2017). Investigation of the pre-service science teachers' pedagogical content knowledge about the nature of science. H.U. Journal of Education, 32(2), 380-395.

Mısır, M. E., ve Laçin-Şimşek, C. (2018). Fen bilgisi öğretmenlerinin bilim tarihinin öğretimsel değeri üzerine görüşleri. Kocaeli Üniversitesi Eğitim Dergisi, 1(1), 1-12.

Miles, M., \& Huberman, M. (1994). An expanded sourcebook qualitative data analysis (2th ed.). Thousand Oaks, CA: Sage publications.

Millar, R., \& Osborne, J. (Eds.) (1998). Beyond 2000. Science education for the future. London: School of Education, King's College London.

Milli Eğitim Bakanlığı [MEB] (2018). Fen bilimleri dersi öğretim programı (İlkokul ve ortaokul 3, 4, 5, 6, 7 ve 8. sinıflar). Ankara: Milli Eğitim Bakanlığı Yayınları.

Milne, C. (1998). Philosophically correct science stories? Examining the implications of heroic science stories for school science. Journal of Research in Science Teaching: The Official Journal of the National Association for Research in Science Teaching, 35(2), 175-187.

Murcia, K., \& Schibeci, R. (1999). Primary student teachers' conceptions of the nature of science. International Journal of Science Education, 21(11), 1123-1140. 
Narguizian, P. J. (2002). The history of science in secondary biology textbooks in the United States: A content analysis (Unpublished doctoral dissertation). University of Southern California, California, USA.

National Research Council [NRC] (2012). A framework for $k$-12 science education: Practices, crosscutting concepts, \& core ideas. Committee on a conceptual framework for new k-12 science education standards. Board on science education, division of behavioral \& social sciences \&education. Washington, DC: The National Academies Press.

Ochanji, M. K. (2003). Learning to teach the nature of science: A study of preservice teachers (Unpublished doctoral dissertation). Syracuse University, USA.

O'neill, J. J. (2007). Prodigal genius: The life of Nikola Tesla. The Book Tree, San Diego, CA. Organisation for Economic Co-operation and Development [OECD] (2013). Draft PISA 2015 science framework. Paris: OECD.

Polat, M. (2018). Bilimin doğası hakkındaki görüşlerin kısa hikâyeler yöntemiyle değerlendirilmesi: Fen bilgisi öğretmen adayları örneği. Maarif Mektepleri Uluslararası Ĕ̈itim Bilimleri Dergisi, 2(1), 19-35.

Polat, M., ve Taşar, M. (2013). Bilimin doğası hakkındaki görüşlerin değerlendirilmesinde alternatif bir yöntem: Kısa hikâyeler yöntemi. Mersin Üniversitesi Eğitim Fakültesi Dergisi, 9(2), 258-274.

Roach, L. E., \& Wandersee, J. H. (1995). Putting people back into science: Using historical vignettes. School Science \&Mathematics, 95(7), 365-370.

Rosell, A. R., \& Vilumara, P. G. (2010). Antoni Quintana-Mari (1907-1998): A pioneer of the use of history of science in science education. Science and Education, 19, 925-929.

Rowcliffe, S. (2004). Storytelling in science. School Science Review, 86(314), 121-126.

Seker, H. (2004). The effect of using the history of science in science lessons on meaningful learning (Unpublished doctoral dissertation). The Ohio State University, USA.

Sönmez, V. (2008). Bilim felsefesi. Ankara: Anı Yayıncılık.

Stinner, A., \& Williams, H. (1993). Conceptual change, history, \& science stories. Interchange, 24(1-2), 87-103.

Şeker, H. (2012). Bilim tarihini öğretimde kullanma modeli. Kuram ve Uygulamada Eğitim Bilim, 12(2), 1141-1158.

Şeker, H., \& Welsh, L. C. (2006). The use of history of mechanics in teaching motion \& force unit. Science and Education, 15(1), 55-89. 
Şimşek, A. (2006). İlköğretim sosyal bilgiler dersinde tarihsel hikâyeye yönelik öğrenci görüşleri. Gazi Üniversitesi Eğitim Fakültesi Dergisi, 26(1), 187-202.

Tez, Z. (1983). "Hayvansal elektrik”den "Volta pili"-ne. Elektrik Mühendisliği, 28(301-302), 139-142.

Topdemir, H. G., ve Unat, Y. (2014). Bilim tarihi. Ankara: Pegem Akademi.

Turgut, H. (2007). Scientific literacy for all. Journal of Faculty of Educational Sciences, 40(2), 233-256.

Wandersee, J. H. (1995). Latour's "inscription device" concept: Is it useful for teaching biology? In F. Finley, D. Allchin, D. Rhees, \& S. Fifield (Eds.), Proceedings volume 2: Third international history, philosophy, \& science teaching conference (pp. 1277-1285). University of Minnesota, College of Education, Minneapolis, Minnesota.

Wang, H. A. (1998). Science in historical perspectives: A content analysis of the history of science in secondary school physics text books. (Unpublished doctoral dissertation). The University of Southern California, Los Angeles, USA.

Wang, H. A., \& Cox-Petersen, A. M. (2002). A comparison of elementary, secondary \& student teachers’ perceptions \& practices related to history of science instruction. Science and Education, 11, 69-81.

Wang, H. A., \& Marsh, D. D. (2002). Science instruction with a humanistic twist: Teachers' perception and practice in using the history of science in their classrooms. Science and Education, 11, 169-189.

Wieder, W. (2006). Science as story: Communicating the nature of science through historical perspectives of science. The American Biology Teacher, 68(4), 200-205.

Yavuzoğlu, Ç. (2018). Süreli çocuk yayınlarının fen bilimleri eğitimi bağlamında bilim tarihi açısından incelenmesi (Yayımlanmamış yüksek lisans tezi). Kastamonu Üniversitesi, Fen Bilimleri Enstitüsü, Kastamonu.

Yıldırım, C. (2016). Bilim tarihi (20. Bask1). İstanbul: Remzi Kitabevi.

Yin, R. K. (2003). Case study research. Design \& methods (3rd ed.). Thous \& Oaks: Sage.

Yücel, M. (2009). Etkileşimli kısa tarihsel hikâyelerin kullanımının ilköğretim ikinci kademe ögrencilerinin bilimin doğasına yönelik anlayışlarını geliştirmesindeki etkililiğ $i$ (Yayımlanmamış yüksek lisans tezi). Gazi Üniversitesi, Eğitim Bilimleri Enstitüsü, Ankara. 


\section{Summary}

\section{Statement of Problem}

Through science education, it is aimed to make students gain scientific understanding about the science concepts, and also to make them understand the nature of science. Related literature has shown that learning about the history of science can help students to improve their understanding of nature of science, and increase their interest or motivation. Because teachers’ knowledge about science concepts and understanding of nature of science is one of the crucial factors affecting students' knowledge and understanding, it is also needed to inform prospective teachers about how they integrate the nature of science in their science classes. One of the most effective ways of integrating the nature of science in science classes is using the historical developments of scientific discoveries. While studying on a science concept with a story based on its history, students learn that why they should learn these concepts and understand the social relevance of science. Storytelling is accepted as a teaching strategy to encourage meaningful learning by allowing students to increase their motivation, improve their imagination, and allow them to look at situations from different viewpoints.

The aim of this study is to carry out two teaching implementations on electricity through stories based on the history of science with the prospective science teachers, and to determine their opinions on the stories based on history of science and the teaching processes.

\section{Method}

This study has been designed according to a holistic single case descriptive study approach and carried out with 11 volunteering second grade prospective science teachers. The intervention including the stories of the construction of the Tesla coil and the Voltaic pile is planned and conducted in line with the LES model. The implementation process based on LES model represented on Table 1.

Table 1. LES Model For Voltaic Pile and Tesla Coil

\begin{tabular}{|c|c|c|}
\hline LES & Voltaic Pile & Tesla Coil \\
\hline $\mathbf{L}$ & \multicolumn{2}{|c|}{$\begin{array}{l}\text { - Starting the process with reading story } \\
\text { - Conducting class discussions at critical points of stories } \\
\text { - Interrupt reading before the main characters’ solution to the problem }\end{array}$} \\
\hline $\mathbf{E}$ & $\begin{array}{l}\text { - Designing prospective teachers' own } \\
\text { experiments to test the Voltaic pile before } \\
\text { reading the section on how to make the pile } \\
\text { - Reading the relevant part of the story } \\
\text { - Installing and running the voltaic pile setup } \\
\text { - Obtaining the prospective teachers' opinions } \\
\text { about the working principle of the pile } \\
\text { - Ending the story and experimental process } \\
\text { with discussion and explanation }\end{array}$ & $\begin{array}{l}\text { - Making prospective teachers' own designs to } \\
\text { ensure the wireless electricity transmission } \\
\text { that Tesla suggested } \\
\text { - Reading the relevant part of the story } \\
\text { - Conducting discussions on the working } \\
\text { principle of Tesla coil setup } \\
\text { - Ending the story and experimental process } \\
\text { with discussion and explanation }\end{array}$ \\
\hline
\end{tabular}


- Conducting discussions about the advantages and disadvantages of Voltaic pile

S

- Obtaining the prospective teachers' opinions about the types of batteries used nowadays, their usage areas, advantages, and disadvantages
- Conducting discussions on the possible changes in the world if the Tesla's Project took place

- Discussing and evaluating Tesla's struggle in scientific, social, and economic contexts

An interview protocol for determining prospective teachers' opinions on the stories and implementation process was used as data collection tool. The interviews were subjected to content analysis, and the data obtained from the analysis classified under themes and categorizes.

\section{Findings}

In conclusion, it was determined that prospective teachers had the opportunity to empathize with the characters in the stories and to evaluate the scientific problems with a critical view point, as well as to express their opinions through classroom discussions. In this context, it is concluded that such teaching practices are effective in ensuring participation in social learning and scientific communication processes. It is also thought that the implementation of science teaching in effective communication environments are provided and will have positive effects on learners' scientific communication skills.

As a result of the teaching practice, it was determined in the prospective teacher's responses to the interview forms that the use of science history-based stories together with LES model provided an effective learning environment. In this context, it is thought that in order to make effective teaching practices, it is necessary to give information to the prospective teachers about the new teaching methods and implement them. For this reason, it is recommended that stories based on history of science and LES model be introduced to prospective teachers in education faculties and to teachers through in-service training.

\section{Discussion and Conclusion}

Considering that the importance of student-centered teaching practices is expressed intensively, it is thought that the teaching practices that will be conducted with stories based on the history of science will provide learning environments that will support learners to understand science concepts. In addition to teaching the subjects and concepts to the learners with stories based on the history of science, the scientists' lives and the historical development of scientific studies can be presented. For this reason, it is thought that writing stories based on the history of science and designing instructional practices in different science subjects and other educational levels will contribute to the field. 